\title{
Growth, Foreign Direct Investment and Urban Concentrations: Unbundling Spatial Lags
}

\author{
STEVEN POELHEKKE \\ FREDERICK VAN DER PLOEG
}

CESIFO WORKING PAPER No. 2474

CATEgORY 7: TRAde Policy

NOVEMBER 2008

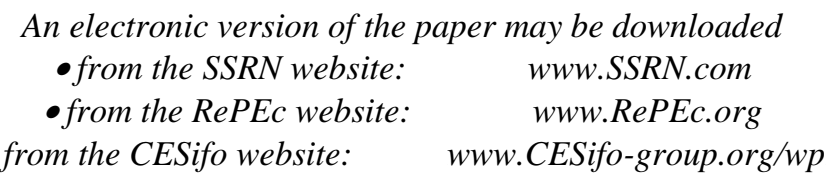




\title{
Growth, Foreign Direct Investment and Urban Concentrations: Unbundling Spatial Lags
}

\begin{abstract}
Cross-country regressions suggest that urbanization and FDI are important drivers of growth. However, it is not clear that primacy eventually hurts growth performance. Since it is tough to interpret cross-country growth regressions, we provide detailed evidence on the determinants of outward FDI from the US. FDI is higher in countries that are close to the US and have good institutions, well developed financial systems, a high road density, a high income per capita and substantial natural resource exports. Countries also attract more FDI if they have more medium-sized cities and primacy is not too large. We show that good institutions in neighbouring countries are important drivers of FDI. FDI is higher if neighbours suffer from primacy. However, FDI is attracted if surrounding countries have fewer cities, restrictions on international trade and low market potential (income per capita). We tentatively conclude that cities are important drivers of FDI and growth and unbundling spatial lags matters. Robustness is verified by re-estimating our regressions with fixed effects and for the sample of OECD countries.
\end{abstract}

JEL Code: C31, F21, F23, F43, O47, R11.

Keywords: growth, foreign investment, cities, urbanization, primacy, spatial lags, spatial autoregression, surrounding market potential, fragmentation, export-platform.

\author{
Steven Poelhekke \\ De Nederlandsche Bank \\ Research Department \\ Westeinde 1 \\ 1017 ZN Amsterdam \\ The Netherlands \\ steven.poelhekke@gmai.com
}

\author{
Frederick van der Ploeg \\ University of Oxford \\ Department of Economics \\ Manor Road \\ Oxford OX1 3UQ \\ United Kingdom \\ rick.vanderploeg@economics.ox.ac.uk
}

Revised November 2008

Presented at the conference 'Are Cities More Important than Countries?' in celebration of the $50^{\text {th }}$ anniversary of the Institute of Housing and Urban Development Studies, Erasmus University, Rotterdam, The Netherlands, 30-31 October 2008. We thank Torfinn Harding, Tony Venables and the participants for helpful comments and discussions. 


\section{Introduction}

More than half the global population now lives in cities. There are more than three hundred city regions with a population greater than a million and at least twenty city regions with a population in excess of ten million. The world is not getting flatter, but if anything the world population and economic activity are more and more concentrated in mega cities. ${ }^{1}$ Policy makers argue that cities are or should be the key drivers of growth performance of their countries and it is cities rather than countries that bend over backwards to attract foreign direct investment (FDI) and skilled labour so that they can improve the welfare of their citizens. Are cities successful because they attract lots of investment including FDI and skilled labour? Or do cities attract economic activity and skilled labour because they are successful? Are cities booming because they are more conducive to international trade and have reliable institutions and better financial centres than rural districts? Are there significant growth-enhancing effects of cities driven by agglomeration advantages? Do excessively large cities suffer from congestion, pollution and other negative externalities and thus become a drag on growth? Reliable answers to these important policy questions are crucial before one could argue that cities are engines of growth for individual countries and thus design policies to enhance growth.

To tackle these issues, we first investigate empirically with the aid of cross-country regressions whether urbanization boosts growth performance and whether primacy indeed harms growth after allowing for the usual controls. We therefore use detailed data on outward FDI for the US to explain the determinants of FDI. We find that FDI is higher in host countries that are close to the US and have good institutions, well developed financial systems, a high road density, a high income per capita and substantial natural resource exports. Countries also attract more FDI if they have more medium-sized cities, but primacy has the opposite effect. We unbundle spatial lags and show that good institutions in neighbouring countries are important drivers of FDI, but urbanization as measured by both primacy and the number of cities, openness and high income per capita in surrounding countries depress FDI. We wrap up by arguing that FDI is a key vehicle for transferring knowledge and technology, thereby increasing productivity growth. Hence, in as far as spatial factors in host and surrounding countries affect FDI, they also affect growth.

We first study the urban determinants of national growth performance building on Henderson (2003), who empirically addresses the question of whether there is some optimal level of urbanization or urban concentration and provides evidence for a non-linear effect of primacy on growth performance. More precisely, cross-country evidence suggests that there is a best degree of urban concentration in tem of maximizing growth in income per capita and that this

\footnotetext{
${ }^{1}$ Some general discussion of the advent of mega cities can be found in Scott et al. (2001), van der Ploeg and Poelhekke (2008) and in much more detail in World Bank (2008).
} 
best degree varies with the size and level of development of the country. The key message appears to be that over- or under-urbanization can be very costly in terms of productivity growth.

Section 2 re-examines this cross-country evidence on urbanization and other drivers of growth performance. In contrast to Henderson (2003), we find no empirical evidence for an optimal degree of urban concentration when we use a larger sample and slightly different variables. If anything, we find the opposite. The share of the biggest city in the total urban population first has a moderately declining and then a moderately increasing effect on annual growth in GDP per capita after controlling for initial GDP per capita, population growth, investment as a fraction of GDP, human capital and openness. The best we can say is that urbanization has a positive effect on growth. Since cross-country regressions are notoriously difficult to interpret, we prefer to investigate more detailed empirical evidence on the urban and other determinants of FDI.

We offer empirical evidence on spatial lags and other determinants of FDI. We follow up and extend the path-breaking work of Blonigen et al. (2007) on the spatial determinants of outward FDI for the US and subsequent work by Garretsen and Peeters (2008) on outward FDI for the Netherlands. Blonigen et al. (2007) uses both national and sector data on outward FDI to find evidence that trade costs, skills, investment costs, distance from the US, GDP, population size and surrounding market potential as well as spatially weighted FDI in neighbouring countries are key determinants of FDI. Their emphasis is on spatial weights to distinguish between four motives for FDI: pure horizontal, export platform, pure vertical and vertical specialization/fragmentation. Their evidence for these motives is mixed and depends on the specific sample of countries and the sectors that are considered. They also offer evidence of additional border effects. Garretsen and Peeters (2008) replicate and extend Blonigen et al. (2007) with Dutch data on FDI and estimate both a spatial lag and a spatial error model to assess the importance of spatial linkages for Dutch FDI to 18 host countries. They find that spatial effects and third-country effects are still significant after controlling for country fixed effects, but that the results are sensitive to sample selection.

The main novelty of our approach is that, instead of spatial lags of FDI, we use spatially weighted measures of surrounding determinants of FDI. We do not only unbundle spatial lags, but also almost double the number of countries included in the analysis which diminishes the bias that arises from arbitrarily excluded countries. Since each of the characteristics of neighbouring countries potentially have different effects on FDI, it is important to unbundle spatial lags.

Inspired by Acemoglu and Johnson (2005), who find evidence that property rights and institutions protecting citizens against expropriation by the government affect growth, we attempt to unbundle spatial lags in our empirical analysis of urban and other determinants of FDI, such as 
by capturing the institutional quality of neighbouring countries. We also distinguish between the effects of the largest city, the distance-weighted size of cities in addition to the number of cities in the host country. We argue that a city is a more attractive market than a dispersed population and we therefore suggest that, even though overall GDP per capita has a positive effect, a more relevant determinant of FDI is accessible GDP in the form of easy-to-reach agglomerations. To allow for the efficiency of cities and the host country, we account for the effects of primacy, quality of institutions and road density (internal infrastructure) on FDI. Spatially weighted surrounding versions of these variables help to discriminate between the various motivations of FDI. Section 3 sets out how economic, urban and institutional characteristics of the host and neighbouring countries affect the various types of FDI (purely horizontal, export platform, purely vertical, and vertical specialization/fragmentation).

Section 4 first reproduces the spatial autoregressive relationships in FDI of Blonigen et al. (2007) and examines the results by extending the sample to a larger group of countries. The empirical evidence suggests that most outward FDI is of the vertical specialization/fragmentation or complex vertical variety. Section 5 then offers detailed empirical evidence which suggests that FDI is not only higher in host countries and that are close to the US and have good institutions, well developed financial systems, a high road density, a large number of medium-sized cities, not too much primacy, a high income per capita and substantial natural resource exports, but FDI also depends on characteristics of neighbouring countries. Our evidence suggests that good institutions in neighbouring countries boost FDI. Bigger primacy problems in surrounding countries depress FDI. However, more FDI is attracted if surrounding countries restrict international trade, have low market potential (measured by income per capita) and have fewer cities. We thus show that urban characteristics of both the host and the neighbouring countries matter for FDI and that a better understanding of FDI requires one to unbundle spatial lags. Furthermore, the urban attributes of neighbouring countries have different effects than other economic and institutional characteristics of neighbouring countries on FDI in the host country. Section 6 checks the robustness of our results by first re-estimating our FDI regressions with fixed effects and then also re-estimating them for the narrower sample of OECD countries.

Section 7 wraps up our arguments that cities and urbanization matter for growth performance by examining the evidence that FDI under the right conditions helps host countries to catch up with the world technology frontier and improve growth performance. In that case, urbanization in host and neighbouring countries will affect growth through its effect on FDI. We prefer this indirect evidence for the effects of cities and urbanization on growth, since the empirical evidence on the determinants of FDI seems more reliable than the cross-country evidence on the urban determinants of growth. Section 8 summarizes our results and concludes 
tentatively that cities are important engines of FDI and growth. We then speculate what these conclusions imply for the potential benefits of regional integration in terms of attracting FDI and enhancing growth performance.

\section{Do Urbanization and Primacy Affect Economic Growth?}

Transformation from a rural agricultural into an industrialized service-based economy typically spurs economic development and leads to urbanization to take advantage of localized economies of scale in manufacturing and services, pooled labour markets and other agglomeration advantages in cities. Many governments facilitate and accelerate the process of urbanization with trade protection, capital market subsidies, public infrastructure and caps on agricultural prices to encourage rural workers to move to cities. Other governments attempt to arrest the process of urbanization by imposing internal migration restrictions. Governments seem to be concerned when cities become too big or small. If one or two mega-cities in their country become too big and suffer from congestion, over-population, crime, social inequality, pollution and other negative externalities, this can stifle growth and become a concern for government. This so-called primacy problem can also be aggravated by political favouritism in efforts to direct resources to the seat of government. ${ }^{2}$ The problem of primacy may encourage the government to develop other urban centres. On the other hand, if there are not enough cities and the rural sectors are too big, countries may not be able to enjoy the fruits of various agglomeration advantages and thus growth and economic development may not take off. There thus appears to be a trade-off between low and high degrees of city concentration. Primacy is bad, but too many small cities may also lead to sub-optimal growth in income per capita.

To test this hypothesis about the effects of urban concentration on growth performance, Henderson (2003) uses a panel dataset covering 70 countries over the period 1960-90 and provides cross-country econometric evidence for a significant quadratic effect of primacy and a negative interaction effects of primacy with initial GDP per capita on growth in GDP per capita, natural land area and national urban population after controlling for the effects of changes in the capital-labour ratio and education on growth in GDP per capita. This suggests that there is an optimal level of primacy in terms of maximizing growth in GDP per capita and that the optimal level of primacy is lower in countries with a high national land area and a high output per worker. Over- or under-concentration of urban centres thus harms productivity growth. Urbanization per

\footnotetext{
${ }^{2}$ Venables (2005) argues that spatial inequality is caused by natural advantages of some regions and by agglomeration forces inducing clustering of economic activity, but increasing returns to scale in cities can lead to sub-optimally sized urban structures. This may depress job creation and retard development. More on primacy can be found in Davis and Henderson (2003), Henderson (2004), Duranton (2007) and van der Ploeg and Poelhekke (2008). Dual housing markets may give rise to urban slums and the primacy problem. The argument that political favouritism can induce primacy is highlighted by Ades and Glaeser (1995).
} 
se does not harm growth, but it does boost growth in the transient phase of development (in line with the Williamson (1965) hypothesis) while primacy stifles growth.

To examine the robustness of the empirical results in Henderson (2003), Table 1 presents cross-country regressions with our sample. The data used are described in Appendix 1.

Table 1: Effects of Urban Concentration on Economic Growth, 1960-2000

\begin{tabular}{|c|c|c|c|c|c|c|}
\hline & (1) OLS & (2) OLS & (3) OLS & (4) DGMM & (5) SGMM & (6) OLS \\
\hline 5-year average yearly growth in GDP per capita & d_gdppc & d_gdppc & d_gdppc & d_gdppc & d_gdppc & d_gdppc \\
\hline \multirow[t]{2}{*}{ Investment share of GDP } & $0.083 * * *$ & $0.088 * * *$ & $0.072 * * *$ & 0.076 & 0.042 & $0.082 * * *$ \\
\hline & $(0.015)$ & $(0.014)$ & $(0.015)$ & $(0.053)$ & $(0.040)$ & $(0.014)$ \\
\hline \multirow[t]{2}{*}{ Average years of total schooling } & -0.001 & 0.000 & -0.000 & -0.003 & 0.001 & -0.000 \\
\hline & $(0.001)$ & $(0.000)$ & $(0.001)$ & $(0.008)$ & $(0.003)$ & $(0.001)$ \\
\hline \multirow{2}{*}{ Primacy (largest city \% of urban population) } & $-0.195 * * *$ & $-0.130 * * *$ & $-0.334 * * *$ & 0.624 & -0.182 & $-0.121 * * *$ \\
\hline & $(0.059)$ & $(0.033)$ & $(0.078)$ & $(1.606)$ & $(0.292)$ & $(0.033)$ \\
\hline \multirow[t]{2}{*}{ Primacy squared } & $0.195^{* * *}$ & $0.187 * * *$ & $0.239 * * *$ & -0.216 & 0.032 & $0.177^{* * *}$ \\
\hline & $(0.049)$ & $(0.049)$ & $(0.051)$ & $(0.522)$ & $(0.197)$ & $(0.049)$ \\
\hline \multirow[t]{2}{*}{ Primacy * GDP per capita } & 0.007 & & -0.001 & -0.108 & -0.010 & \\
\hline & $(0.005)$ & & $(0.006)$ & $(0.072)$ & $(0.026)$ & \\
\hline \multirow[t]{2}{*}{ Primacy * $\ln$ urban population } & & & $0.011^{* * *}$ & 0.002 & 0.011 & \\
\hline & & & $(0.003)$ & $(0.045)$ & $(0.015)$ & \\
\hline \multirow[t]{2}{*}{ Primacy * land area } & & & 0.002 & 0.023 & 0.004 & \\
\hline & & & $(0.003)$ & $(0.068)$ & $(0.008)$ & \\
\hline \multirow[t]{2}{*}{ log GDP per capita } & & & & & & $-0.005^{* *}$ \\
\hline & & & & & & $(0.002)$ \\
\hline \multirow[t]{2}{*}{ Openness to trade (Sachs \& Warner) } & & & & & & $0.012^{* * *}$ \\
\hline & & & & & & $(0.003)$ \\
\hline \multirow[t]{2}{*}{\begin{tabular}{|l|} 
Average yearly population growth rate \\
\end{tabular}} & & & & & & $-0.322 * *$ \\
\hline & & & & & & $(0.141)$ \\
\hline \multirow[t]{2}{*}{ Constant } & $0.036^{* * *}$ & $0.031^{* * *}$ & $0.039 * * *$ & & 0.032 & $0.074 * * *$ \\
\hline & $(0.007)$ & $(0.006)$ & $(0.007)$ & & $(0.025)$ & $(0.017)$ \\
\hline Observations & 630 & 630 & 621 & 550 & 621 & 630 \\
\hline R-squared & 0.19 & 0.18 & 0.20 & . & . & 0.22 \\
\hline year dummies & yes & yes & yes & yes & yes & yes \\
\hline Sargan test, p-value & & & & 0.064 & & \\
\hline Hansen test, p-value & & & & & 0.984 & \\
\hline Number of countries & 71 & 71 & 70 & 70 & 70 & 71 \\
\hline
\end{tabular}

Extending the sample to 71 countries and 40 years, we find that annual growth in GDP per capita is higher in countries with higher rates of investment as a fraction of GDP, but do not find a significant effect of schooling. Regression (6) suggests that countries with low initial levels of GDP per capita catch up quicker and that growth is higher in countries with low population growth and high degrees of openness to international trade. These correspond to the usual determinants in the empirical cross-country literature on the determinants of growth. In addition, regression (6) offers some evidence for a significant nonlinear effect of primacy on growth. 
However, Figure 1 shows that the estimated conditional effect of primacy on growth performance is modest and negative. In contrast to Henderson (1973), we find that intermediate degrees of primacy have a slightly more negative effect on annual growth than low and very high degrees of primacy. Our regressions thus do not confirm that mega-cities and high primacy curb growth prospects. The unconditional correlation shows a modest positive effect of primacy on growth.

\section{Figure 1: Conditional effect of primacy on annual growth per capita}

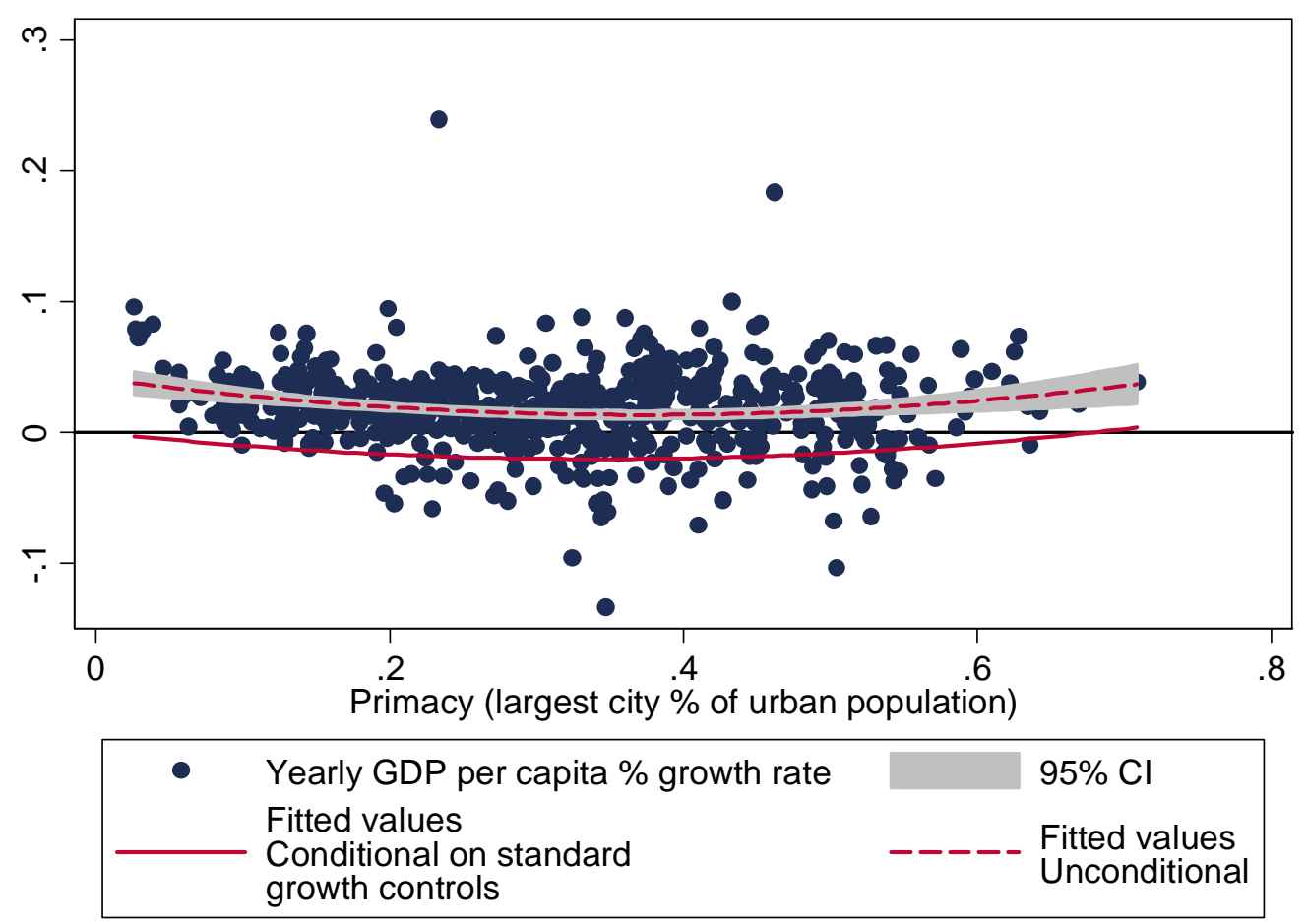

Our sample could not replicate the results that the optimal level of primacy is lower in countries with a high national land area and a high output per worker either - see regressions (1)-(5). If anything, regression (3) seems to indicate that high levels of primacy harm growth less in countries with a large urban population. The main lesson seems to be, however, that one has to be very careful in interpreting cross-country results on the relationship between primacy and growth.

More recently, Brülhart and Sbergami (2008) have extended Henderson (2003) to a world-wide sample of 105 countries and a narrower sample of Western European countries over the period 1960-2000 using Theil indices of intra-country geographic concentration based on data for sub-national regions as a complement to more conventional urbanization measures. ${ }^{3}$ They thus

\footnotetext{
${ }^{3}$ Crozet and Koenig (2008) use data on EU regions at the NUTS3 level over the period 1980-2000 and obtain evidence which suggests that regions with more uneven spatial distribution of productions grow faster, at least for the northern regions in the EU. Bosker (2008), however, using a sample of 250 regions
} 
offer extensive cross-country OLS and improved dynamic panel system GMM estimates (Blundell and Bond, 1998) of the effects of urbanization and primacy on the rate of economic growth. They find empirical support for Williamson’s (1965) hypothesis that agglomeration boosts growth in GDP per capita only up to a certain level of economic development. ${ }^{4}$ Their choice of estimator is a significantly improved version of the Arellano and Bond (1991) difference GMM estimator used by Henderson (2003).

When we employ both estimators in regressions (4) and (5), we still cannot replicate the same effects. The instability of the estimates may be explained by the high multicollinearity between the primacy measures. Table 2 shows that all cross-correlations are above 0.93 . There thus does not seem to be enough variation in the data to distinguish the nonlinear effects of primacy on growth. This can cause the coefficients to have the wrong sign and standard errors to be too large for all the estimators used, even in system GMM. In regression (6) we therefore remove the interactions, but add several standard growth controls. We still find a negative effect of primacy on growth which becomes positive at higher levels of primacy.

Table 2: Cross-correlations for sample regression (3) in Table 1

\begin{tabular}{|l|r|l|l|l|l|}
\hline & Primacy & $\begin{array}{l}\text { Primacy } \\
\text { squared }\end{array}$ & $\begin{array}{l}\text { Primacy * GDP } \\
\text { per capita }\end{array}$ & $\begin{array}{l}\text { Primacy * In urban } \\
\text { population }\end{array}$ & $\begin{array}{l}\text { Primacy * land } \\
\text { area }\end{array}$ \\
\hline & & & & & \\
\hline Primacy & 1 & & & & \\
\hline Primacy squared & 0.9714 & 1 & & & \\
\hline Primacy * GDP per capita & 0.9589 & 0.9275 & 1 & & \\
\hline Primacy * ln urban population & 0.9783 & 0.9356 & 0.9680 & & \\
\hline Primacy * land area & 0.9687 & 0.9399 & 0.9317 & 0.9544 & \\
\hline
\end{tabular}

Summing up, we find some empirical evidence that primacy is an important driver of national growth performance. But we realize that our results on the effects of urbanization on growth performance, like those of Henderson (2003) and Brülhart and Sbergami (2008), are highly sensitive to the particular sample of countries and time periods that are chosen and the list of explanatory variables that is included. This is why different studies find that there is either an optimal degree of urban concentration or a modest effect of urbanization on growth or an effect of agglomeration on growth only for low levels of development. Interpreting the estimated

over 25 years finds that, on average, denser regions grow slower than other regions indicating a negative effect of agglomeration but also finds that being close to fast growing region boosts growth.

4 They estimate that the critical level is about USD 10,000 in 2006 prices, roughly the current per-capita income of Brazil or Bulgaria. Their study thus suggests that effects of higher agglomeration on growth taper off as the country becomes richer, so poor countries that inhibit big city formation hinder growth. 
coefficients in cross-country growth regressions is notoriously difficult. ${ }^{5}$ Interpretation of empirical results is even more difficult if data on primacy and urbanization are strongly correlated with other determinants of economic growth. For example, the theory, case studies and crosscountry evidence offered by Ades and Glaeser (1995) suggest that high tariffs, low levels of international trade and political instability increase the degree of urban concentration but these same variables may be expected to have a direct negative effect on growth performance.

The roadmap of the remainder of our paper is therefore as follows. We first discuss in section 3 the potential host and neighbouring country determinants of various types of FDI and in sections 4 and 5 offer empirical evidence on, respectively, spatial lags of FDI and the spatial determinants of FDI. Our results suggest that urbanization both in the host and neighbouring countries are key determinants of FDI. We then argue in section 6 that under the right conditions FDI boosts growth and helps host countries catch up with the world technology frontier. Urbanization may thus improve growth performance indirectly through its effect on FDI. We prefer this indirect approach, since we trust our estimated effects of urbanization on FDI more than cross-country estimates of urbanization on growth of individual countries.

\section{Host and Neighbouring Country Determinants on Various Types of FDI}

In the interpretation of our empirical results, it helps to distinguish four rationales for FDI:

- Purely horizontal: FDI arises from a market-access motive to substitute for export flows; trade costs and thus distance from the home market make it more attractive to produce existing products in the host country close to the market, especially if the host country has a large market potential;

- Export platform: FDI occurs when a parent company invests in a host country in order to serve third markets with exports of final goods from the affiliate in the host country; distance from the home country, cheaper production in the host than in the home country and a market potential in countries surrounding the host country induces FDI;

- Purely vertical: FDI occurs if the parent company is fragmenting its production process to foreign sites $^{6}$ in order to have cheaper access to factor inputs abroad; the host country is a cheap production site for the home market in which case better quality of neighbouring sites decrease FDI while market potential is not the main motive; and

\footnotetext{
${ }^{5}$ Using cross-country data to estimate the effects of institutions at home and in neighbouring countries on variations in income per capita seems to yield results that are more robust to alternative specifications of relative geography, sample size and inclusion of additional controls (Bosker and Garretsen, 2008). ${ }^{6}$ FDI can establish a downstream/forward affiliate that buys products from the parent company or a upstream/backward affiliate that supplies intermediates to the parent company. Off-shoring occurs if an entire part of the production process of the parent company is moved abroad.
} 
- Vertical specialization/fragmentation: occurs if the parent company fragments its production process and directs FDI towards the host country for off-shoring part of its production chain.

Markusen (1984) and Helpman (1984) have analyzed, respectively, horizontal and vertical FDI within a general equilibrium framework. A state-of-the art analysis of the theoretical and empirical FDI issues can be found in Barba-Navaretti et al. (2004). Much of the empirical work on FDI has employed the gravity model, which suggests that market size of the host country and distance from the country of the parent company are key determinants of FDI. Ekholm et al. (2007) offer an export-platform explanation and Baltagi et al. (2007) stress the complex vertical nature of FDI with exports of intermediate inputs from affiliates to third markets for further processing before being shipped to the final destination. Both these latter explanations depart from earlier two-country models and stress the effect of third countries on FDI in host countries. The key insight is, however, that FDI decisions across host countries are not independent and the econometric analysis thus needs to allow for spatial interdependence to avoid biased estimates.

The proximity-concentration trade-off for horizontal FDI suggests that it pays to locate closer to a larger host market (as measured by population size and income per capita) with favourable conditions (e.g., openness, good institutions, well developed financial system) especially if one can save on high transport and trading costs (including tariffs, efficiency of ports and transport, and corruption in customs) to make it worthwhile to produce in multiple locations and have an affiliate in a host country. As long as exports from third countries are unattractive, one would expect a zero coefficient for the spatial lag on horizontal FDI and one would not expect an effect of surrounding market potential on horizontal FDI either. One expects a zero coefficient on surrounding market potential. However, a negative coefficient may indicate that there is fierce competition for FDI, so FDI goes to countries with the biggest market potential.

One well-located affiliate in a host country which also serves surrounding countries is called export-platform FDI. It many of the proximity benefits of horizontal FDI without incurring additional costs of setting up affiliates in each of the surrounding countries. With less trade protection between destination markets than frictions between the parent and destination countries, export-platform FDI is attractive and one would expect a negative coefficient for the spatial lag on export-platform FDI and a positive coefficient for surrounding market potential. FDI to the platform affiliate then substitutes for FDI to surrounding markets and serves surrounding markets from the host market.

However, Blonigen et al. (2007) argue that the coefficient on surrounding market potential may be negative if border costs between the host country and its neighbours are significant and the potential host country is relatively large in market size but is not centrally 
located within the group of surrounding countries. With intermediate levels of border costs between the host and surrounding countries, it is interesting to set up an export-platform affiliate and to do this not necessarily in the country with the greatest surrounding market potential which might be a small centrally located host country but in a large, peripheral host country. In such a setting, border costs imply that there may be a negative relationship between surrounding market potential and FDI. So, the negative coefficient on surrounding market potential offers empirical support for the border cost hypothesis.

With purely vertical FDI one also expects a negative coefficient for the spatial lag on FDI, since multinationals seek the lowest-cost destination of the activity they want to relocate and thus FDI in one country may harm FDI in neighbouring countries. There should be no effect of surrounding market potential on purely vertical FDI, since the affiliate's output is shipped back to the parent company. With vertical specialization/fragmentation FDI one expects a positive coefficient for the spatial lag on FDI, since having more suppliers and other agglomeration advantages (e.g., airports or ports) in surrounding countries makes fragmentation FDI in the host country more attractive. Again, one would not expect an effect of surrounding market potential on fragmentation FDI but a negative coefficient on surrounding GDP per capita would suggest evidence for the border cost hypothesis.

The discussion so far is summarized by the 'spatial lags on FDI' and 'surrounding market potential-GDP per capita' rows in Table 3. By examining the signs of these two effects in the regression results, one may identify which particular type of FDI is more prevalent than other forms of FDI. No horizontal lag on FDI implies horizontal FDI, a positive lag suggests fragmentation FDI, and a negative lag indicates either export-platform or vertical FDI. In fact, it is hard to identify whether it is export-platform or vertical FDI as the coefficient on surrounding GDP per capita may be insignificant even with vertical FDI if the expected positive effect and the negative effect arising from the border cost hypothesis offset each other. We attempt to differentiate between these various types of FDI in the estimates discussed in section 4 .

In sections 5 and 6, however, we argue that restricting the effects of surrounding countries to spatial lags of FDI is itself too restrictive and that a better understanding of FDI is gained when the spatial lags are unbundled. We thus estimate the effects of a wide range of host and neighbouring countries' attributes on FDI. Effectively, we estimate separately the effects of surrounding market potential factors and surrounding trade costs and production costs factors on FDI and thus shed more detailed light on the four types of FDI. Although Blonigen et al. (2007) and Garretsen and Peeters (2008) explain outward FDI to various countries with spatial lag and spatial error models, we know of no empirical studies that unbundle the spatial determinants of 
FDI. The empirical literature so far considers distance from the country that is sending the FDI, market potential, skills and trade costs including quality of institutions in the host country, and FDI in neighbouring countries (i.e., spatial lags of FDI) as determinants of FDI. It is essential to distinguish explicitly between internal and surrounding country characteristics; for example, we expect local and surrounding openness to international trade to have very different effects on FDI, depending on which type of FDI is most prevalent. Location is furthermore usually not considered as a factor determining FDI and the term agglomeration mostly refers to clustering between proximate countries. Agglomerations of cities in the host and neighbouring countries and the internal geography of the host country have thus far not been included in cross-country studies as determinants of FDI. But such spatial variables may be at least as important as the quality of institutions in the host country. ${ }^{78} 910$ In contrast to earlier studies, we also allow for the effects of accessible market potential on FDI.

So what are the possible links between cities and FDI? First, market potential is more accessible if it is located in one city as this reduces transportation costs within the host country. Market potential is also more accessible if there is good network of roads, railroads, ports, and airports. Second, cities form around important growth-enhancing inputs such as ports and resources and also enjoy agglomeration advantages, all of which are relevant for FDI. More cities in the host country therefore give a higher chance of offering FDI the right type of specific inputs,

\footnotetext{
${ }^{7}$ Wheeler and Mody (1992) use US data to explain outward electronics and manufacturing FDI. They rely on tournaments between states through (tax) incentives. Firms may spread risk across locations, unless agglomeration forces are strong enough. They use host market size, openness, relative labour costs, relative tax rates, and (perceived) risk to explain FDI. They expect openness to have a negative sign, since the focus is on horizontal FDI (import substitution, protection from competing imports).

${ }^{8}$ Coughlin and Segev (2000), however, offer within-country evidence that US FDI in Chinese provinces is positively related to US FDI in neighbouring provinces. However, Amiti and Javorcik (200) find, using information on 515 Chinese industries at the provincial level during 1998-2001, that access to markets and suppliers matter more than access to the rest of China which is consistent with underdeveloped transport infrastructure and informal trade barriers. Baltagi et al. (2007) also uses spatial econometrics to estimate the effects of third countries on US outward FDI for seven manufacturing industries, but find it tough to differentiate between export-platform FDI and complex vertical FDI.

${ }^{9}$ Bobonis and Shatz's (2007) within-country study on the spatial determinants of inward FDI to various US states tries to separate agglomeration effects from an effect arising from adjustment of the rate of capital, where the desired stock of capital in each state depends on market and labour market variables, geography, state policies, and lagged capital in own and neighbouring states. They find a smaller agglomeration effect than previously reported. Unfortunately, their estimates are based on the biased difference GMM-estimator - see, for example, Bond (2002).

${ }^{10}$ Head et al. (1995) also study the effects of agglomeration on FDI. They focus on horizontal Japanese manufacturing investments in US states and allow states to compete for FDI through corporate taxes, Free Trade Zones and job creation subsidies and also allow for an effect of state income, adjacent income, within-state agglomeration and adjacent agglomeration on FDI. Competition effects are important, so the overall state effect on distribution of FDI is small. Head and Mayer (2004) perform a similar exercise for the determinants of Japanese FDI in the European Union and empirically demonstrate the effect of market potential, both GDP of the host country and that of adjacent regions weighted by distance and other trade frictions, for FDI. Unfortunately, these two studies only explain discrete measures of FDI.
} 
especially if they are near the 'focal point' of a country (being the location of its largest city). Third, cities are more likely to attract a concentration of motivated, often high-skilled labour. Fourth, as discussed in section 2, cities can become inefficiently large and succumb to the primacy problem. Congestion, pollution, over-population and other negative externalities then outweigh scale economies. There are thus various reasons why both the number of cities and primacy (measured by the share of the largest one city in the urban population) in the host country may affect FDI. To the extent that there are spatial lags, the number of cities, primacy and road networks in neighbouring countries will also affect FDI in the host country. The key empirical question is whether it is feasible to separate the effects of cities, urban concentration, road networks, etc. from institutions while discriminating between the four motives of FDI.

To better understand these rationales for different types of FDI, Table 3 summarizes which host and neighbouring country variables should affect FDI in the host country and also whether the expected effect on FDI is positive, negative or zero for each of the four types of FDI.

Trade costs capture several dimensions in which trade may be hampered. If the main reason for FDI is to facilitate expansion into markets which are hard to reach by simply shipping goods from the home country, we expect a negative effect of openness to trade of the host country. Internal road density makes the whole host market easier to reach, but this is less relevant for other types of FDI. On the other hand, if the main motivation is to produce goods cheaply and ship them back to the home market (vertical FDI), then openness and ports are needed to make this possible. Financial development and the quality of institutions should generally provide the means to set up a successful business, regardless of which type of FDI is more prevalent. The signs switch for surrounding trade costs, mainly because if neighbouring countries provide better conditions, then the host country probably is not the preferred location and therefore attracts less FDI. We thus expect vertical FDI to be higher if surrounding countries have trade restrictions and fewer roads and ports, but fragmentation FDI to be lower. Exportplatform FDI benefits from more roads and ports in surrounding countries and trade openness. Poor institutions and badly developed financial systems in surrounding countries hurt most nonhorizontal forms of FDI.

Market potential in the host country is of importance to home firms seeking to sell in the host market. A wealthier market is more interesting, but we also hypothesize that the degree to which this market can be reached through concentrated activity determines its attractiveness. Arguably, the urban Chinese population is more attractive than the much larger rural population. The effects on vertically oriented FDI are more ambiguous, but probably lie instead with their effects on production costs. Surrounding market potential is irrelevant for firms seeking to sell only in the host country, but very relevant for firms seeking to use the host country as a hub from 
which to serve the entire region. A neighbouring large city will also be interesting. Obviously, surrounding market potential is irrelevant if the goal is to sell at home as with horizontal FDI.

Table 3: Host and Neighbouring Country Determinants for Four Types of FDI

\begin{tabular}{|c|c|c|c|c|}
\hline & \begin{tabular}{|l|} 
Purely \\
horizontal
\end{tabular} & $\begin{array}{l}\text { Export- } \\
\text { platform }\end{array}$ & $\begin{array}{l}\text { Purely } \\
\text { vertical }\end{array}$ & $\begin{array}{l}\text { Export } \\
\text { specialization/ } \\
\text { fragmentation }\end{array}$ \\
\hline Spatial lag on FDI & 0 & - & - & + \\
\hline $\begin{array}{l}\text { Distance US } \\
\text { Skill level }\end{array}$ & $\begin{array}{l}- \\
+\end{array}$ & $\begin{array}{l}0 \\
+\end{array}$ & $\begin{array}{l}- \\
+\end{array}$ & $\begin{array}{ll}- \\
+\end{array}$ \\
\hline $\begin{array}{l}\text { Trade costs: } \\
\text { Openness } \\
\text { Financial development } \\
\text { Institutions (law, corruption, } \\
\text { bureaucracy) } \\
\text { Road density } \\
\text { Number of ports }\end{array}$ & $\begin{array}{l}- \\
+ \\
+ \\
+ \\
+ \\
0\end{array}$ & $\begin{array}{l}+ \\
+ \\
+ \\
+ \\
0 \\
+\end{array}$ & $\begin{array}{l}+ \\
+ \\
+ \\
0 \\
+\end{array}$ & $\begin{array}{l}+ \\
+ \\
+ \\
+ \\
+\end{array}$ \\
\hline $\begin{array}{l}\text { Internal market potential: } \\
\text { GDP per capita } \\
\text { \% Urban population (accessible } \\
\text { market potential) } \\
\text { Primacy (city inefficiency) }\end{array}$ & $\begin{array}{l}+ \\
+ \\
-\end{array}$ & $\begin{array}{l}0 \\
0 \\
0\end{array}$ & $\begin{array}{l}0 \\
0 \\
0\end{array}$ & $\begin{array}{l}0 \\
0 \\
0\end{array}$ \\
\hline $\begin{array}{l}\text { Production costs (location, scale): } \\
\text { Distance-weighted number of } \\
\text { standard size cities } \\
\text { Natural resources }\end{array}$ & $\begin{array}{r}0 \\
+\end{array}$ & $\begin{array}{l}0 \\
+\end{array}$ & $\begin{array}{l}+ \\
+\end{array}$ & $\begin{array}{l}+ \\
+\end{array}$ \\
\hline $\begin{array}{l}\text { Surrounding market potential: } \\
\text { GDP per capita } \\
\text { \%Urban population (accessible } \\
\text { market potential) } \\
\text { Primacy (city inefficiency) }\end{array}$ & $\begin{array}{l}0 \\
0 \\
0\end{array}$ & $\begin{array}{l}+/(-) \\
+ \\
0\end{array}$ & $\begin{array}{l}0 \\
0 \\
+ \\
\end{array}$ & $\begin{array}{l}(-) \\
+ \\
+ \\
+\end{array}$ \\
\hline $\begin{array}{l}\text { Surrounding production costs: } \\
\text { Distance weighted number of standard } \\
\text { size cities } \\
\text { Natural resources }\end{array}$ & $\begin{array}{l}0 \\
0\end{array}$ & $\begin{array}{l}0 \\
-\end{array}$ & - & - \\
\hline $\begin{array}{l}\text { Surrounding trade costs: } \\
\text { Openness } \\
\text { Financial development } \\
\text { Institutions (rule of law, corruption, } \\
\text { bureaucracy) } \\
\text { Road density } \\
\text { Number of ports }\end{array}$ & $\begin{array}{l}0 \\
0 \\
0 \\
0 \\
0\end{array}$ & $\begin{array}{l}+ \\
- \\
- \\
+ \\
+\end{array}$ & $\begin{array}{l}- \\
- \\
- \\
- \\
-\end{array}$ & $\begin{array}{l}+ \\
0 \\
0 \\
+ \\
+\end{array}$ \\
\hline
\end{tabular}


Production costs are not necessarily an obstacle to firms who simply aim to sell locally, but are certainly important for vertical production chains. More cities offer more locations for production and a higher chance that a foreign firm will find a location with suitable comparative advantage for its specific activity. A country with more cities of sufficient size offers the benefits of agglomeration economies in combination with the benefits of multiple locations. We are able to make a distinction between the absolute number of cities and the number of standard size cities (in this case 750,000 people), where we weigh all cities by their distance from the largest city and rescale the weighted total in terms of cities of a standard size. We hypothesize that more cities is a bonus in the race for FDI, but not if they are very far apart or far from a main centre of activity, which is usually also a country's main port. Russia for example has many cities, but they tend to be far away from ports and therefore less attractive to FDI than the multiple of German cities in the neighbourhood of, say, the port of Hamburg or the river port of Essen. In addition, internal geography has different implications than external geography of surrounding countries. The former will have a positive effect on vertical FDI, while the latter a negative effect, meaning that other surrounding countries offer good substitute locations. Natural and other resources, an input in production, are expected to have a positive effect.

The matrix of expected signs summarized in Table 3 thus offers us the ability to distinguish between on the one hand the effects of institutions versus the effects of agglomerations and cities, while revealing the most prevalent type of FDI. Future research on the sector level should be able to better discriminate among the four types of FDI. In section 5 we test empirically hypotheses put forward in Table 3 and section 6 investigates the robustness of our results with respect to country fixed effects and using the sample of OECD countries.

\section{Spatial Autoregression and Determinants of FDI}

We focus on outward FDI for the US. Since there are many measures of FDI (e.g., portfolio FDI, mergers and acquisitions), we use a measure of FDI that corresponds to affiliate sales from the Bureau of Economic Analysis. ${ }^{11}$ In line with the OECD Benchmark Definition of Foreign Direct Investment ( $3^{\text {rd }}$ edition, 1999), the data only considers affiliates where the US parent company has at least $10 \%$ control. This should permit the parent company to exercise control and influence and participate in the affiliate. The FDI data we use therefore only measures revenue flows from FDI rather than flow changes due to changes in, say, the valuation of the existing stock of FDI. This definition of FDI has some limitations, since cases of passive stock ownership are classified as FDI. Furthermore, long-term contracts and other non-equity relationships between multinationals

\footnotetext{
${ }^{11}$ Data, from Blonigen et al. (2007), are deflated with a price index for gross domestic investment from the Economic Report of the President. The series ends in 1998, since a different definition is used after 1998.
} 
and affiliates are not classified as FDI. With $N$ potential host countries and $T$ years of observation, we use these FDI data to estimate the following spatial vector autoregression:

$$
\ln (f d i)=\alpha_{0}+\alpha_{1} \text { Host variables }+\alpha_{2} \text { Surrounding Market Potential }+\rho W \ln (f d i)+\varepsilon,
$$

$$
\text { where } W \equiv\left(\begin{array}{ccc}
W_{1} & 0 & 0 \\
0 & . . & 0 \\
0 & 0 & W_{T}
\end{array}\right), W_{t} \equiv\left(\begin{array}{cccc}
0 & 115.4 / d_{1,2} & . . & 115.4 / d_{N, 1} \\
115.4 / d_{2,1} & 0 & . . & 115.4 / d_{N, 2} \\
. . & . . & . . & . . \\
115.4 / d_{N, 1} & 115.4 / d_{N, 2} & . . & 0
\end{array}\right) \text {, }
$$

$\operatorname{Ln}(f d i)$ is the $N T x 1$ vector of outward US FDI to all the host countries, the host variables are population, trade costs, skill level, investment costs, distance from the US and GDP of the host country, the surrounding market potential is captured by the log of the inverse-distance-weighted GDP of all surrounding countries, the block-diagonal matrix $W$ corresponds to the spatial lag weighting matrix with each block along the diagonal corresponding to a single year ${ }^{12}, \rho$ stands for the spatial autocorrelation coefficient, and $\varepsilon$ corresponds to the $N T \mathrm{x} 1$ vector of error terms. The host variables distance, host GDP, trade and investment frictions, and surrounding market potential are inspired by the well known gravity model. Population is included, since higher population reduces ceteris paribus GDP per capita and thus FDI. Population controls for the tendency of FDI to move between wealthy markets.

The vector $\rho W \ln (f d i)$ captures the proximity of each host country to all the other neighbouring host countries. The blocks along the matrix $\mathrm{W}$ depend on distances, so are the same for each year. The off-diagonal elements in each block contain the spatial inverse-distance weights between any two potential host countries, where the distances correspond to the Vincenty (1975) differences in kilometres between country centroids and are normalized by the shortest distance between two host countries (the distance between Netherlands and Belgium, i.e., 115.4 $\mathrm{km}){ }^{13}$ The remaining data are described in Appendix 2 and the sample of countries that Blonigen et al. (2007) and the extended sample that we use are given in Appendix 3. Appendix 4 presents some stylized facts of the spatial characteristics of the countries in our sample.

The results from Blonigen et al. (2007) clearly reject a common coefficient on host GDP and their measure of surrounding market potential. Their results suggest that export-platform FDI may be important for the more developed European countries. They also find that estimated

\footnotetext{
${ }^{12}$ We do not row-standardize the weighting matrix to stay close toHead and Mayer (2004).

${ }^{13}$ Blonigen et al. (2007) use the shortest bilateral distance between capital cities, which is not necessarily the most appropriate measure. For example, a lot of economic activity is concentrated in Rotterdam and Antwerp rather than in Amsterdam and Brussels which would lead to a shorter, relevant distance.
} 
relationships of traditional determinants of US outward FDI for the period 1983-98 are fairly robust to inclusion of terms to capture spatial interdependence, even though these terms are significant. But the traditional determinants of FDI and the estimated spatial interdependence are quite sensitive to the sample of countries that is used.

Table 4 therefore presents our estimated spatial autoregressive relationships for outward US FDI during the period 1983-1998 for various samples of countries. ${ }^{14}$ Regressions (1) and (2) correspond to regressions 4 and 5 using the same sample as in Blonigen et al. (2007, p. 1315) while regressions (3) and (4) extend the results to a sample with a larger number of countries. ${ }^{15}$

We find that a bigger market potential, a higher level of education, lower trade costs and investment costs in the host country attract more FDI. Regressions (1) and (3) also suggest that a shorter distance from the country of the parent company attracts more FDI. Turning to the spatial determinants of FDI, the evidence suggests that there is a negative effect of surrounding market potential on FDI and a positive contemporaneous correlation between FDI in the host country and FDI in neighbouring countries. This confirms the main finding of Blonigen et al. (2007).

Regressions (1) and (2) restrict attention to the sample of Blonigen et al. (2007). The spatial lags remain significant. Also, the coefficient on surrounding market potential stays significant, once we allow control for time-invariant unobserved fixed effects specific to each country (as is the case for non-OECD countries in Blonigen et al. (2007)). The difference may be caused by our different choice of distance metric. However, in regression (4) for our extended sample with the same variables we have a larger negative and significant coefficient on surrounding market potential while the positive coefficient on the spatial lags is lower and slightly less significant once we allow for country dummies. Given that country dummies pick up spatial interactions that can be expected to be fairly constant over time, it is not surprising that the spatial lag coefficients are somewhat smaller after controlling for country fixed effects. A $10 \%$ higher distance-weighted FDI going into surrounding areas implies 4\% higher FDI.

Given the discussion in section 3, our empirical evidence suggests that most of outward US FDI is of the complex vertical or vertical specialization/fragmentation variety, because purely horizontal FDI would imply no spatial lag while purely vertical or export-platform FDI would imply a negative spatial lag. At first sight the negative coefficient on surrounding market potential

\footnotetext{
${ }^{14}$ We use OLS to estimate (1). Although ML may yield consistent estimates, we allow for a larger sample and Blonigen et al. (2007, p1309) report that their coefficients of their main explanatory variables are not affected by endogeneity of lagged FDI. The larger sample helps, since for (say) investment costs we do not have observations for all countries. We can also deal with unbalanced panels. We use all available observations so as not to arbitrarily omit countries from the spatial lags, just because we miss observations on other variables for this country. We may thus have less measurement error, even though we use OLS. ${ }^{15}$ We allow for arbitrary heteroskedasticity in all regressions, because a Breusch-Pagan /Cook-Weisberg test for heteroskedasticity rejects constant variance in regression (1) at the 89\% confidence level, and very strongly in the larger sample used in regression (3).
} 
may appear puzzling, but it may arise if border costs between the host country and its neighbours are significant and the potential host country is relatively large in market size but not centrally located within the group of surrounding countries. So, the negative coefficient on surrounding market potential offers empirical support for the border cost hypothesis.

Table 4: Spatial Autoregressive Relationships in FDI

\begin{tabular}{|c|c|c|c|c|c|}
\hline & & (1) & (2) & (3) & (4) \\
\hline & & $\operatorname{lnfdi}$ & $\operatorname{lnfdi}$ & $\operatorname{lnfdi}$ & $\operatorname{lnfdi}$ \\
\hline \multirow[t]{2}{*}{ In_poptot } & In population & $-0.551^{* * *}$ & -0.591 & $-1.024 * * *$ & $-1.202^{* * *}$ \\
\hline & & $(0.074)$ & $(0.361)$ & $(0.151)$ & $(0.355)$ \\
\hline \multirow[t]{2}{*}{ Lntc } & In trade costs & $-0.917 * * *$ & -0.066 & $-1.083^{* * *}$ & -0.259 \\
\hline & & $(0.071)$ & $(0.096)$ & (0.096) & (0.159) \\
\hline \multirow[t]{2}{*}{ Inhumanav } & In human capital & $0.183 *$ & $0.450 * *$ & 0.072 & $0.429 * *$ \\
\hline & & $(0.105)$ & $(0.183)$ & $(0.176)$ & $(0.194)$ \\
\hline \multirow[t]{2}{*}{ Ininvcost } & In investment costs & $-1.141 * * *$ & $-0.866 * * *$ & -0.550 & $-1.037 * * *$ \\
\hline & & $(0.181)$ & $(0.170)$ & $(0.338)$ & $(0.181)$ \\
\hline \multirow[t]{2}{*}{ In_dist } & In distance from US & $-0.877 * * *$ & 0.000 & $-1.010 * * *$ & 0.000 \\
\hline & & $(0.061)$ & $(0.000)$ & $(0.087)$ & $(0.000)$ \\
\hline \multirow[t]{2}{*}{ trend } & time trend & -0.010 & 0.005 & -0.001 & 0.028 \\
\hline & & $(0.030)$ & $(0.017)$ & $(0.041)$ & $(0.028)$ \\
\hline \multirow[t]{2}{*}{ trendsq } & time trend squared & 0.001 & $0.002^{* * *}$ & 0.001 & $0.002 * *$ \\
\hline & & $(0.001)$ & $(0.001)$ & $(0.002)$ & $(0.001)$ \\
\hline \multirow[t]{2}{*}{ lngdp } & $\ln$ GDP & $1.750^{* * *}$ & $1.167^{* * *}$ & $2.129 * * *$ & $1.950^{* * *}$ \\
\hline & & $(0.085)$ & $(0.140)$ & $(0.152)$ & $(0.271)$ \\
\hline \multirow[t]{2}{*}{ lngdp_smp } & ln GDP, surrounding & $-1.105^{* * *}$ & $-1.514^{* * *}$ & $-1.236 * * *$ & $-2.732 * * *$ \\
\hline & & $(0.291)$ & $(0.375)$ & $(0.325)$ & $(0.511)$ \\
\hline \multirow[t]{2}{*}{ Infdi_smp } & In FDI, surrounding & $0.482^{* * *}$ & $0.449 * * *$ & $0.463 * *$ & $0.400 *$ \\
\hline & & $(0.175)$ & $(0.146)$ & $(0.193)$ & $(0.216)$ \\
\hline \multirow[t]{2}{*}{ Constant } & & $6.944 * * *$ & $9.338 * * *$ & $13.609 * * *$ & $17.845^{* * *}$ \\
\hline & & $(0.961)$ & (3.508) & (1.879) & (4.209) \\
\hline Country dummies & & No & Yes & No & Yes \\
\hline Observations & & 553 & 553 & 633 & 633 \\
\hline R-squared & & 0.86 & 0.77 & 0.80 & 0.71 \\
\hline
\end{tabular}

\section{Empirical Evidence for Host and Neighbouring Country Urbanization on FDI}

Our main empirical contribution is threefold: we extend the 'market potential' and 'surrounding market potential' with data on cities; we highlight accessible market potential; and we unbundle spatial lags. For the time being, we use a restricted number of cities of a certain size, urbanisation and degree of primacy. In future work, we like to use internal spatially weighted urban market potential (e.g., the largest city as possible focal point for FDI including a weighting of a number 
of smaller cities with their distance to the largest city or the number of harbour cities and their size as a focal point for FDI). It would also be useful to disentangle host trade cost and to allow for the influence of institutions. Allowing for accessible market potential and unbundling spatial lags thus suggests that we estimate the following vector regression:

ln fdi $=\beta_{0}+\beta_{1}$ Host market potential $+\beta_{2}$ Host production costs $+\beta_{3}$ Host trade costs $+\beta_{4}$ Surrounding Market Potential $+\beta_{5}$ Surrounding production costs $+\beta_{6}$ Surrounding trade costs $+\varepsilon$,

where the explanatory variables and the expected signs of their effects on FDI are discussed in section 3 and summarized in Table 3.

Table 5 offers some fairly standard regressions where only market potential and host country characteristics are considered. Regression (1) is limited to the sample countries used in Blonigen et al. (2007) and regression (2) is estimated from a sample of countries that are not included in that analysis. Regression (3) combines the two samples. Appendix 3 lists the countries of both samples. Distance from the US has a negative effect on FDI, echoing the negative distance effect of trade in general. Interestingly, in the sample of additional countries, which consists of mostly developing countries, we see that openness now plays a much smaller role while the quality of institutions as measured by the rule of law, corruption and the quality of bureaucracy is much more important. Also, human capital seems to be more important for attracting FDI in this sample of mostly developing economies. Countries with higher GDP attract more FDI, while a large population implies lower GDP per capita and decreases FDI. Surrounding market potential has a negative effect on attracting FDI, albeit much smaller in the whole sample. These results offer some support for the border cost hypothesis and suggest that vertical-type FDI is most common.

Regression (4) adds other relevant determinants of FDI. These do not change our qualitative results much, but suggest that well developed financial markets and a high road density make it easier to attract FDI. Being surrounded by land seems to attract FDI, which seems odd as such countries tend to be remote from main trade routes. One possible explanation might be that landlocked countries are backward and thus may have many potential gains from FDI in roads and airports to make them less remote. 
Table 5: Determinants of FDI when Unbundling Spatial Lags, 1984-1998

\begin{tabular}{|c|c|c|c|c|c|c|}
\hline & & $\begin{array}{c}\text { Blonigen et } \\
\text { al. sample }\end{array}$ & $\begin{array}{c}\text { Extra } \\
\text { sample }\end{array}$ & $\begin{array}{c}\text { Combined } \\
\text { sample }\end{array}$ & $\begin{array}{c}\text { With extra } \\
\text { determinants }\end{array}$ & $\begin{array}{c}\text { Also with } \\
\text { spatial lags }\end{array}$ \\
\hline & & (1) & (2) & (3) & (4) & (5) \\
\hline Determinant & Mmenomic & $\operatorname{lnfdi}$ & lnfdi & lnfdi & lnfdi & lnfdi \\
\hline \multirow[t]{2}{*}{ In_dist } & In distance from USA (Vincenty) & $-0.487 * * *$ & $-1.429 * * *$ & $-0.874^{* * *}$ & $-1.036^{* * *}$ & $-0.984 * * *$ \\
\hline & & $(0.072)$ & $(0.129)$ & $(0.083)$ & $(0.089)$ & $(0.137)$ \\
\hline \multirow[t]{2}{*}{ Inhumanav } & In human capital & 0.052 & $0.783^{* * *}$ & $0.627^{* * *}$ & $0.286 * * *$ & $0.258^{* *}$ \\
\hline & & $(0.175)$ & $(0.160)$ & $(0.147)$ & $(0.103)$ & $(0.108)$ \\
\hline \multirow[t]{2}{*}{ openness } & S\&W openness & $0.237 * * *$ & -0.099 & $0.419 * * *$ & $0.208^{*}$ & $0.254^{* *}$ \\
\hline & & $(0.088)$ & $(0.136)$ & $(0.116)$ & $(0.109)$ & $(0.108)$ \\
\hline \multirow[t]{2}{*}{ Ininst } & $\begin{array}{l}\text { In Institutions (Corruption, rule of law, } \\
\text { bureaucracy, higher = less risk) }\end{array}$ & -0.050 & $0.685^{* * *}$ & $0.697 * * *$ & $0.673^{* * *}$ & $0.490 * * *$ \\
\hline & & $(0.138)$ & $(0.115)$ & $(0.121)$ & $(0.128)$ & $(0.115)$ \\
\hline \multirow[t]{2}{*}{ lngdp } & In GDP in billions & $1.846^{* * *}$ & $0.723^{* * *}$ & $1.302^{* * *}$ & $1.218^{* * *}$ & $1.171^{* * *}$ \\
\hline & & $(0.125)$ & $(0.125)$ & $(0.101)$ & $(0.088)$ & $(0.100)$ \\
\hline \multirow[t]{2}{*}{ In_poptot } & In population & $-0.947 * * *$ & -0.163 & $-0.487 * * *$ & $-0.283^{* * *}$ & $-0.228 * *$ \\
\hline & & $(0.138)$ & $(0.115)$ & $(0.105)$ & $(0.093)$ & $(0.104)$ \\
\hline \multirow[t]{2}{*}{ Ingdp_smp } & In GDP surrounding market potential & 0.017 & $-2.143 * * *$ & $-0.162 * *$ & $-0.500 * * *$ & $-1.322 * * *$ \\
\hline & & $(0.067)$ & $(0.322)$ & $(0.079)$ & $(0.112)$ & $(0.347)$ \\
\hline \multirow[t]{2}{*}{ trend } & trend & $0.018^{* *}$ & $0.081^{* * *}$ & 0.003 & 0.004 & $0.048^{* * *}$ \\
\hline & & $(0.008)$ & $(0.019)$ & $(0.009)$ & $(0.009)$ & $(0.012)$ \\
\hline \multirow[t]{2}{*}{ Constant } & Constant & $12.788^{* * *}$ & $28.041^{* * *}$ & $12.805^{* * *}$ & $16.227^{* * *}$ & $27.236^{* * *}$ \\
\hline & & $(1.320)$ & $(2.479)$ & $(1.082)$ & $(1.190)$ & $(2.681)$ \\
\hline \multirow[t]{2}{*}{ Infindev } & In fin. development (private credit/GDP) & & & & $0.242^{* * *}$ & $0.329 * * *$ \\
\hline & & & & & $(0.063)$ & $(0.069)$ \\
\hline \multirow[t]{2}{*}{ landlock } & LANDLOCK & & & & $0.628^{* * *}$ & $0.621^{* * *}$ \\
\hline & & & & & $(0.127)$ & $(0.135)$ \\
\hline \multirow[t]{2}{*}{ Inroadens } & In Road Density & & & & $0.290 * * *$ & $0.368^{* * *}$ \\
\hline & & & & & $(0.053)$ & $(0.052)$ \\
\hline \multirow[t]{2}{*}{ Inopenness_smp } & In S\&W openness, surrounding & & & & & $-0.572 * * *$ \\
\hline & & & & & & $(0.168)$ \\
\hline \multirow[t]{2}{*}{ Ininst_smp } & In Insitutions, surrounding & & & & & 0.296 \\
\hline & & & & & & $(0.356)$ \\
\hline \multirow[t]{2}{*}{ Inpoptot_smp } & In population, surrounding & & & & & $-0.649 * * *$ \\
\hline & & & & & & $(0.220)$ \\
\hline \multirow[t]{2}{*}{ Infindev_smp } & $\begin{array}{l}\text { In fin. development (private credit/GDP), } \\
\text { surrounding }\end{array}$ & & & & & 0.332 \\
\hline & & & & & & $(0.410)$ \\
\hline \multirow[t]{2}{*}{ Inroadens_smp } & In Road density, surrounding & & & & & $0.799 * * *$ \\
\hline & & & & & & $(0.199)$ \\
\hline Observations & & 511 & 480 & 991 & 895 & 895 \\
\hline R-squared & & 0.76 & 0.56 & 0.78 & 0.83 & 0.85 \\
\hline Countries & & 35 & 42 & 76 & 75 & 75 \\
\hline
\end{tabular}


Regression (5) progresses the analysis towards our main hypotheses, namely that spatially weighted determinants of FDI such as neighbouring openness to trade have important implications. Spatially lagged openness and population enter negatively, suggesting that if neighbouring countries are better locations, then FDI will not move into the host country. This fits well with vertical FDI, but less with export-oriented FDI, which actually needs openness of surrounding countries. In favour of the latter type of FDI, good surrounding transport infrastructure does attract FDI. However, these results may be biased as they do not take into account other possible drivers, such as agglomerations. Table 6 will therefore further investigate this hypothesis.

Regression (6) includes all variables which we expect to impact the location of FDI. Newly included variables which capture the internal and surrounding geography of cities often enter the regression significantly. However, our analysis also suffers from lack of variation in the data. Several variables are highly correlated and can therefore not be separately identified within the same model. The correlation of the data for spatially weighted income per capita with financial development in surrounding countries is 0.96 , and 0.95 with surrounding road density. This reflects general clustering of wealthier and poorer countries in the global economy. Also the correlation of the spatially weighted rate of urbanization with income per capita is 0.96 . We therefore drop these variables in regression (7). This adjustment turns out to be important: human capital and being landlocked no longer predict FDI inflow from the US. Most vertical FDI from the US is probably not very skill intensive. However, we still face some multicollinearity between spatially weighted income per capita and spatially weighted institutions. Since both effects may be important, we exclude each one of them, one at a time, in regressions (8) and (9). Both are insignificant while the other coefficients hardly change. This leads us to a more structural interpretation of the results.

Concerning internal market characteristics, we find evidence in favour of horizontal FDI. While openness to trade is not important, we find that a good financial infrastructure and competent institutions matter much more in the race for FDI. High income per capita makes it worthwhile to produce and sell locally and the amount of infrastructure helps to reach more consumers. Accessibility of consumers is also important. Although the conditional effect of the percentage of urban dwellers is not significant, we find strong results for the number of standard size cities, weighted by their distance from the largest city. However, it does not seem the case that concentration of activity in a single city is beneficial: primacy actually deters foreign direct investment. Primate cities have often grown too large, so that congestion costs may have become larger than possible agglomeration benefits. Conditional on the effects of institutions and internal market potential, we find that agglomerations are attractors of FDI if they are of efficient size. 
Table 6: Replacing Total Population With Accessible Market Potential and Cities, 1984-98

\begin{tabular}{|c|c|c|c|c|c|c|c|}
\hline & & & & \multicolumn{2}{|c|}{ Core results } & \multicolumn{2}{|c|}{ With natural resources } \\
\hline & & (6) & (7) & (8) & (9) & $(10)$ & $(11)$ \\
\hline Mnemonic & Determinant & lnfdi & lnfdi & lnfdi & lnfdi & $\operatorname{lnfdi}$ & lnfdi \\
\hline \multirow[t]{2}{*}{ In_dist } & In distance from USA (Vincenty) & $-1.156 * * *$ & $-0.689 * * *$ & $-0.682 * * *$ & $-0.679 * * *$ & $-0.701 * * *$ & $-0.708^{* * *}$ \\
\hline & & $(0.117)$ & $(0.105)$ & $(0.104)$ & $(0.104)$ & $(0.086)$ & $(0.090)$ \\
\hline \multirow[t]{2}{*}{ Inhumanav } & In human capital & $0.295^{* *}$ & 0.153 & 0.157 & 0.171 & $0.353^{* *}$ & $0.368 * *$ \\
\hline & & $(0.121)$ & $(0.131)$ & $(0.130)$ & $(0.129)$ & $(0.156)$ & $(0.156)$ \\
\hline \multirow[t]{2}{*}{ openness } & S\&W openness & 0.016 & 0.184 & 0.190 & 0.203 & 0.019 & 0.052 \\
\hline & & $(0.126)$ & $(0.130)$ & $(0.130)$ & $(0.128)$ & $(0.134)$ & $(0.132)$ \\
\hline \multirow[t]{2}{*}{ lnfindev } & $\begin{array}{l}\text { In fin. development (private } \\
\text { credit/GDP) }\end{array}$ & $0.245^{* * *}$ & $0.339 * * *$ & $0.330 * * *$ & $0.336 * * *$ & $0.389 * * *$ & $0.398 * * *$ \\
\hline & & $(0.062)$ & $(0.069)$ & $(0.068)$ & $(0.069)$ & $(0.068)$ & $(0.069)$ \\
\hline \multirow[t]{2}{*}{ Ininst } & $\begin{array}{l}\text { In Institutions (Corruption, rule of } \\
\text { law, bureaucracy, higher = less } \\
\text { risk) }\end{array}$ & $0.386^{* * *}$ & $0.356^{* * *}$ & $0.364^{* * *}$ & $0.376^{* * *}$ & -0.016 & 0.022 \\
\hline & & $(0.121)$ & $(0.133)$ & $(0.134)$ & $(0.133)$ & $(0.112)$ & $(0.114)$ \\
\hline \multirow[t]{2}{*}{ Ingdppc } & In GDP per capita & $1.222 * * *$ & $1.301^{* * *}$ & $1.297 * * *$ & $1.246^{* * *}$ & $1.847^{* * *}$ & $1.735^{* * *}$ \\
\hline & & $(0.109)$ & $(0.129)$ & $(0.128)$ & $(0.121)$ & $(0.134)$ & $(0.128)$ \\
\hline \multirow[t]{2}{*}{ Inroadens } & In Road Density & $0.275^{* * *}$ & $0.376^{* * *}$ & $0.380^{* * *}$ & $0.378 * * *$ & $0.403^{* * *}$ & $0.402^{* * *}$ \\
\hline & & $(0.052)$ & $(0.058)$ & $(0.059)$ & $(0.059)$ & $(0.051)$ & $(0.051)$ \\
\hline \multirow[t]{2}{*}{ landlock } & LANDLOCK & $0.324 * * *$ & 0.126 & 0.128 & 0.121 & $0.274^{* *}$ & $0.256^{* *}$ \\
\hline & & $(0.115)$ & $(0.117)$ & $(0.117)$ & $(0.117)$ & $(0.128)$ & $(0.126)$ \\
\hline \multirow[t]{2}{*}{ urbpav } & $\%$ urban population & 0.004 & $-0.715^{* *}$ & $-0.741^{* *}$ & $-0.715^{* *}$ & $-2.419 * * *$ & $-2.349 * * *$ \\
\hline & & $(0.296)$ & $(0.353)$ & $(0.353)$ & $(0.356)$ & $(0.327)$ & $(0.328)$ \\
\hline \multirow[t]{2}{*}{ primacy } & $\begin{array}{l}\text { Primacy (largest city \% urban } \\
\text { pop.) }\end{array}$ & $-1.275^{* * *}$ & $-2.454 * * *$ & $-2.406 * * *$ & $-2.286 * * *$ & $-2.398 * * *$ & $-2.122 * * *$ \\
\hline & & $(0.343)$ & $(0.339)$ & $(0.335)$ & $(0.309)$ & $(0.295)$ & $(0.267)$ \\
\hline \multirow[t]{2}{*}{ Incitycountall } & $\ln \#$ cities $>0$ & 0.070 & 0.028 & 0.031 & 0.040 & $0.135 * *$ & $0.150 * *$ \\
\hline & & $(0.065)$ & $(0.071)$ & $(0.071)$ & $(0.070)$ & $(0.059)$ & $(0.058)$ \\
\hline \multirow[t]{2}{*}{ Incitynumber_mp } & $\begin{array}{l}\text { In City number, weighted by } \\
\text { distance, within country in } \\
750,000 \text { equivalent }\end{array}$ & $0.859 * * *$ & $0.838 * * *$ & $0.833^{* * *}$ & $0.831^{* * *}$ & $1.151^{* * *}$ & $1.140^{* * *}$ \\
\hline & & $(0.060)$ & $(0.069)$ & $(0.069)$ & $(0.068)$ & $(0.066)$ & $(0.066)$ \\
\hline \multirow[t]{2}{*}{ Infindev_smp } & $\begin{array}{l}\text { In fin. development (private } \\
\text { credit/GDP), surrounding }\end{array}$ & $1.515^{* * *}$ & & & & & \\
\hline & & $(0.403)$ & & & & & \\
\hline \multirow[t]{2}{*}{ Ininst_smp } & In Insitutions, surrounding & 0.261 & 0.443 & & -0.039 & & $-0.436^{*}$ \\
\hline & & $(0.372)$ & $(0.410)$ & & $(0.240)$ & & $(0.258)$ \\
\hline \multirow[t]{2}{*}{ lngdppc_smp } & $\begin{array}{l}\text { In GDP per capita, surrounding } \\
\text { market potential }\end{array}$ & $-3.369 * * *$ & -0.447 & -0.191 & & $-0.583 * * *$ & \\
\hline & & $(0.413)$ & $(0.316)$ & $(0.185)$ & & $(0.184)$ & \\
\hline \multirow[t]{2}{*}{ Inroadens_smp } & In Road density, surrounding & $2.748 * * *$ & & & & & \\
\hline & & $(0.280)$ & & & & & \\
\hline \multirow[t]{2}{*}{ urbpav_smp } & $\%$ urban population, surrounding & -0.295 & & & & & \\
\hline & & $(0.185)$ & & & & & \\
\hline \multirow[t]{2}{*}{ primacy_smp } & Primacy, surrounding & $0.654 * * *$ & $0.621^{* * *}$ & $0.709 * * *$ & $0.666^{* * *}$ & $0.961^{* * *}$ & $0.949 * * *$ \\
\hline & & $(0.176)$ & $(0.181)$ & $(0.159)$ & $(0.175)$ & $(0.164)$ & $(0.173)$ \\
\hline
\end{tabular}




\begin{tabular}{|c|c|c|c|c|c|c|c|}
\hline Incitynumber_smp & $\begin{array}{l}\text { In City number, weighted by } \\
\text { distance, all surrounding countries }\end{array}$ & $-1.842 * * *$ & $-0.825 * * *$ & $-0.817 * * *$ & $-0.877 * * *$ & $-0.485 * * *$ & $-0.592 * * *$ \\
\hline & & $(0.218)$ & $(0.187)$ & $(0.187)$ & $(0.189)$ & $(0.154)$ & $(0.163)$ \\
\hline \multirow[t]{2}{*}{ Inopenness_smp } & In S\&W openness, surrounding & $-0.945 * * *$ & $-0.455^{* * *}$ & $-0.387 * *$ & $-0.478 * * *$ & -0.135 & -0.253 \\
\hline & & $(0.178)$ & $(0.176)$ & (0.169) & $(0.176)$ & $(0.180)$ & $(0.189)$ \\
\hline \multirow[t]{2}{*}{ trend } & & $0.064 * * *$ & $0.045^{* * *}$ & $0.045^{* * *}$ & $0.049 * * *$ & $0.045^{* * *}$ & $0.052^{* * *}$ \\
\hline & & $(0.012)$ & $(0.011)$ & $(0.011)$ & $(0.011)$ & $(0.010)$ & $(0.010)$ \\
\hline \multirow[t]{2}{*}{ Constant } & & $32.407 * * *$ & $5.642 *$ & $4.247 *$ & 2.437 & $10.316^{* * *}$ & $5.809 * * *$ \\
\hline & & (3.948) & $(2.942)$ & $(2.526)$ & $(1.805)$ & $(2.287)$ & $(1.617)$ \\
\hline \multirow[t]{2}{*}{ Innatpoint } & $\begin{array}{l}\text { In share of point-source natural } \\
\text { resource exports in GDP }\end{array}$ & & & & & $0.598 * * *$ & $0.590 * * *$ \\
\hline & & & & & & $(0.054)$ & $(0.053)$ \\
\hline \multirow[t]{2}{*}{ Innatpoint_smp } & $\begin{array}{l}\text { In share of point-source natural } \\
\text { resource exports in GDP, } \\
\text { surrounding }\end{array}$ & & & & & 0.190 & 0.168 \\
\hline & & & & & & $(0.159)$ & $(0.168)$ \\
\hline Observations & & 813 & 813 & 813 & 813 & 758 & 758 \\
\hline R-squared & & 0.87 & 0.85 & 0.85 & 0.85 & 0.86 & 0.86 \\
\hline Countries & & 67 & 67 & 67 & 67 & 66 & 66 \\
\hline
\end{tabular}

None of the surrounding variables should affect pure horizontal FDI, but for vertical FDI they do matter. Turning to surrounding country characteristics, we see that if neighbouring countries offer better locations for FDI, such as a fair amount of medium-sized cities and low levels of primacy, US parent companies are less likely to invest in the host economy. We find little evidence of export-platform FDI, because surrounding income per capita should be important and our results show that it is not. The empirical evidence points more towards vertical or complex vertical FDI.

Concern for inconsistency in spatial autoregressive regressions comes from the spatially lagged dependent variable itself in equation (1), which is endogenous. In our estimated model (2) we do not include the lag of FDI itself, but rather its determinants, where we make an explicit distinction between internal and external determinants. Unlike the spatially lagged dependent variable (i.e., lagged FDI), these explanatory variables are not necessarily correlated with the error term. Furthermore, by distinguishing between internal and surrounding determinants, we spatial lags are less likely to be correlated with the error through for example a correlation between a national characteristic and the host country error term. For example, if an unobserved national institution drives both internal GDP and FDI simultaneously, then market potential in the standard sense (internal GDP plus a spatial weight of GDP) would be endogenous. It is much less likely that the hypothetical host country institution also drives surrounding GDP. However, our richer dataset allows us to capture many of the institutional, geographical and other features of a country which may affect FDI, leaving less space for any unobserved influences. Furthermore, it is unlikely that host country FDI will affect initial institutional quality (up to five years back) through reverse causation or affect any of the weighted surrounding country features. 
We may have omitted two variables which capture an important dimension of production costs. A lot of FDI is directed towards natural resource extraction, either for the home market or as input in local production of final goods. Producing close to these inputs saves on transportation costs. The latter can be very relevant for heavy mining products. Adding local and surrounding export values of point-source natural resources as a share of GDP ${ }^{16}$ changes the picture a little see regression (10). ${ }^{17}$ Institutions are less important if natural resource wealth is present, while surrounding market potential (income per capita) becomes significantly negative, pointing towards the complex-vertical model of FDI. Resources in the host country countries affect FDI positively. Mining resources can be a strong motivation for FDI and an input in the vertical production chain. The estimated negative effect of surrounding market potential (measured by GDP per capita) on FDI may also arise with export-platform affiliates in not centrally located countries with a large market size.

The key result that can be gleaned from regressions (10) and (11) is that natural resource dependence both in the host and surrounding countries exerts a strong positive effect on FDI. We report a particularly strong effect for point-source natural resources. This result sheds a different perspective on the resource literature emanating from Sachs and Warner (1997) who offer crosscountry empirical support for a significant negative effect of natural resource dependence on the rate of economic growth. One reason why the so-called resource curse does not seem to apply to FDI may be that the mining and mineral sectors attract a boom in capital-intensive FDI, especially for point-source natural resources. In future work we will use FDI data at the sector level to examine whether natural resource dependence induces a boom in mining and mineral FDI and whether such a boom is partially offset by a decline in FDI in other sectors of the economy or not. This seems important, since the growth-enhancing effects of FDI in manufacturing, services and even agriculture seems to be higher than that of FDI in the extractive industries. If FDI in the rest of the economy is indeed crowded out, this may diminish employment, linkages to the domestic economy and growth externalities.

\section{Robustness: Fixed effects and OECD Sample}

Blonigen et al. (2007) find that, after allowing for country fixed effects, the estimated spatial determinants often become insignificant. Furthermore, the estimated spatial determinants are highly sensitive to the particular sample that is chosen. To examine the robustness of our

\footnotetext{
${ }^{16}$ Including fuels, ores and metals. These are called point-source as they compact, highly valuable and produced in a few locations.

${ }^{17}$ As an additional test to see if we have captured all the important spatially lagged information, we calculated the spatial autocorrelation coefficient of the error term. This term was not significantly different from zero in regressions (10) and (11), thus rejecting residual spatial autocorrelation.
} 
empirical results on the host and neighbouring countries determinants of FDI, Table 7 therefore re-estimates the last two regressions reported in Table 6 with fixed effects and then with the narrower sample of OECD countries. Distance, whether a country is landlocked and the number of cities in the host and surrounding countries are absorbed in the country fixed effects, but not the spatially weighted amount of standard size cities (due to the effect of population growth over the sample and its effect on the standard size cities). Openness to trade is also not absorbed in the country fixed effects, because several countries opened up to trade during the sample period 1984-98.

Compared to regressions (10) and (11) of Table 6, we find that fixed effects absorb a big chunk of the previously estimated effects. This may be due to the sluggish and path-dependent nature of institutional change and changes in the urban landscape during the relatively short period of fifteen years. We find support for a negative effect of host country primacy and openness in neighbouring countries on FDI and a positive effect of internal market potential, skills and natural resources. While countries with a higher degree of resource production attract FDI (see regression (10) in Table 6), a country which increases its share of natural resources over the sample period now negatively affects FDI (compare with regression (12) in Table 7).

The estimated coefficients for the OECD sample look much more similar to those of regressions (10) and (11) in Table 6. We still find important effects of agglomerations (both their number and efficiency) in the host country. Surrounding market potential is much more important: there is more evidence that export-platform FDI takes place in the OECD, where this was not the case for our global sample. A country's openness is important within the OECD. However, this is entirely driven by New Zealand and Turkey, who became more open to trade only in respectively 1986 and 1989. Many other spatially lagged variables are less significant, probably due to the general similarity of OECD countries over both space and time. The OECD sample contains very similar countries. Although this may make it easier to identify the main type of FDI, multicollinearity is a serious problem as spatially weighted versions of institutions, openness, primacy, the absolute number of cities and internally weighted number of standard-size cities are highly correlated. The OECD results should therefore be interpreted with caution. 
Table 7: FDI Regressions with Country Fixed Effects, 1984-1998

\begin{tabular}{|c|c|c|c|c|c|}
\hline & & \multicolumn{2}{|c|}{ Global Sample } & \multicolumn{2}{|c|}{ OECD Sample } \\
\hline & & $(12)$ & $(13)$ & $(14)$ & $(15)$ \\
\hline & & $\operatorname{lnfdi}$ & Infdi & $\operatorname{lnfdi}$ & $\operatorname{lnfdi}$ \\
\hline In_dist & In distance from USA (Vincenty) & & & & \\
\hline \multirow[t]{2}{*}{ Inhumanav } & In human capital & $0.713^{* * *}$ & $0.717^{* * *}$ & 0.351 & 0.133 \\
\hline & & $(0.261)$ & $(0.260)$ & $(0.296)$ & $(0.296)$ \\
\hline \multirow[t]{2}{*}{ openness } & S\&W openness & 0.024 & 0.025 & $0.380 * * *$ & $0.370 * * *$ \\
\hline & & $(0.059)$ & $(0.058)$ & $(0.095)$ & $(0.097)$ \\
\hline \multirow[t]{2}{*}{ Infindev } & $\begin{array}{l}\text { In fin. development (private } \\
\text { credit/GDP) }\end{array}$ & -0.034 & -0.033 & $0.068^{*}$ & 0.066 \\
\hline & & $(0.101)$ & $(0.101)$ & $(0.039)$ & $(0.040)$ \\
\hline \multirow[t]{2}{*}{ lninst } & $\begin{array}{l}\text { In Institutions (Corruption, rule of } \\
\text { law, bureaucracy, higher = less risk) }\end{array}$ & 0.013 & 0.018 & $0.190 * *$ & $0.190 * *$ \\
\hline & & $(0.062)$ & $(0.068)$ & $(0.094)$ & $(0.096)$ \\
\hline \multirow[t]{2}{*}{ lngdppc } & In GDP per capita & $0.691^{* * *}$ & $0.698^{* * *}$ & $0.854 * * *$ & $0.927 * * *$ \\
\hline & & $(0.190)$ & $(0.175)$ & $(0.208)$ & $(0.195)$ \\
\hline \multirow[t]{2}{*}{ Inroadens } & In Road Density & -0.013 & -0.013 & -0.038 & -0.012 \\
\hline & & $(0.107)$ & $(0.106)$ & $(0.035)$ & $(0.038)$ \\
\hline \multirow[t]{2}{*}{ urbpav } & $\%$ urban population & 1.192 & 1.166 & $-3.613^{* * *}$ & $-2.892 * *$ \\
\hline & & $(1.198)$ & $(1.201)$ & $(1.181)$ & $(1.175)$ \\
\hline \multirow[t]{2}{*}{ primacy } & Primacy (largest city \% urban pop.) & $-2.970 *$ & $-3.020 *$ & $-4.880 * * *$ & $-4.230 * *$ \\
\hline & & $(1.615)$ & $(1.633)$ & $(1.700)$ & $(1.663)$ \\
\hline \multirow[t]{2}{*}{ Incitynumber_mp } & $\begin{array}{l}\text { In City number, weighted by distance, } \\
\text { within country in } 750,000 \text { equivalent }\end{array}$ & -0.277 & -0.268 & $1.464 * * *$ & $1.335^{* * *}$ \\
\hline & & $(0.295)$ & $(0.295)$ & $(0.402)$ & $(0.392)$ \\
\hline \multirow[t]{2}{*}{ lngdppc_smp } & $\begin{array}{l}\text { In GDP per capita, surrounding market } \\
\text { potential }\end{array}$ & 0.221 & & $1.843^{* * *}$ & \\
\hline & & $(0.684)$ & & $(0.538)$ & \\
\hline \multirow[t]{2}{*}{ Ininst_smp } & In Insitutions, surrounding & & -0.072 & & $-0.396 * *$ \\
\hline & & & $(0.265)$ & & $(0.176)$ \\
\hline \multirow[t]{2}{*}{ primacy_smp } & Primacy, surrounding & -2.523 & -2.521 & -1.056 & -2.375 \\
\hline & & $(1.718)$ & $(1.594)$ & $(2.129)$ & $(2.160)$ \\
\hline \multirow[t]{2}{*}{ Incitynumber_smp } & \begin{tabular}{|l|} 
In City number, weighted by distance, \\
all surrounding countries
\end{tabular} & $-0.933 * *$ & $-0.879 * *$ & -0.351 & -0.058 \\
\hline & & $(0.463)$ & $(0.439)$ & $(0.408)$ & $(0.397)$ \\
\hline \multirow[t]{2}{*}{ lnopenness_smp } & In S\&W openness, surrounding & $-0.295 * * *$ & $-0.307 * * *$ & 0.025 & 0.037 \\
\hline & & $(0.111)$ & $(0.101)$ & $(0.150)$ & $(0.157)$ \\
\hline \multirow[t]{2}{*}{ trend } & & $0.063^{* * *}$ & $0.068 * * *$ & -0.003 & $0.035^{* * *}$ \\
\hline & & $(0.018)$ & $(0.012)$ & $(0.012)$ & $(0.008)$ \\
\hline \multirow[t]{2}{*}{ Innatpoint } & $\begin{array}{l}\text { In share of point-source resources } \\
\text { exports in GDP }\end{array}$ & $-0.123 * * *$ & $-0.125^{* * *}$ & $-0.210^{* * *}$ & $-0.206^{* * *}$ \\
\hline & & $(0.040)$ & $(0.040)$ & $(0.042)$ & $(0.043)$ \\
\hline \multirow[t]{2}{*}{ Innatpoint_smp } & $\begin{array}{l}\text { In share of point-source resources } \\
\text { exports in GDP, surrounding }\end{array}$ & $0.133 * *$ & $0.126 * *$ & $0.259 * * *$ & $0.198 * * *$ \\
\hline & & $(0.058)$ & $(0.059)$ & $(0.063)$ & $(0.060)$ \\
\hline \multirow[t]{2}{*}{ Constant } & & -5.698 & -3.012 & -8.017 & $13.835^{* * *}$ \\
\hline & & $(6.945)$ & $(4.542)$ & $(7.190)$ & $(4.354)$ \\
\hline Observations & & 758 & 758 & 326 & 326 \\
\hline \# countries & & 66 & 66 & 23 & 23 \\
\hline R-squared & & 0.53 & 0.53 & 0.87 & 0.87 \\
\hline
\end{tabular}




\section{Does FDI Boost Economic Growth? ${ }^{18}$}

The stock of global FDI has grown from a little over 5\% of global GDP in 1980 to 20 to $25 \%$ of global GDP in recent years. Global FDI stock has thus grown at a faster pace than global GDP. Markusen (2002) points out that FDI has grown each year by about a third during the late 1990s while exports and world GDP grew only at an annual rate of $1.5 \%$ and $0.6 \%$, respectively. Figure 2 indicates that world-wide US outward FDI flows have also more than doubled in fifteen years.

Figure 2: Spectacular growth of outward FDI for the US

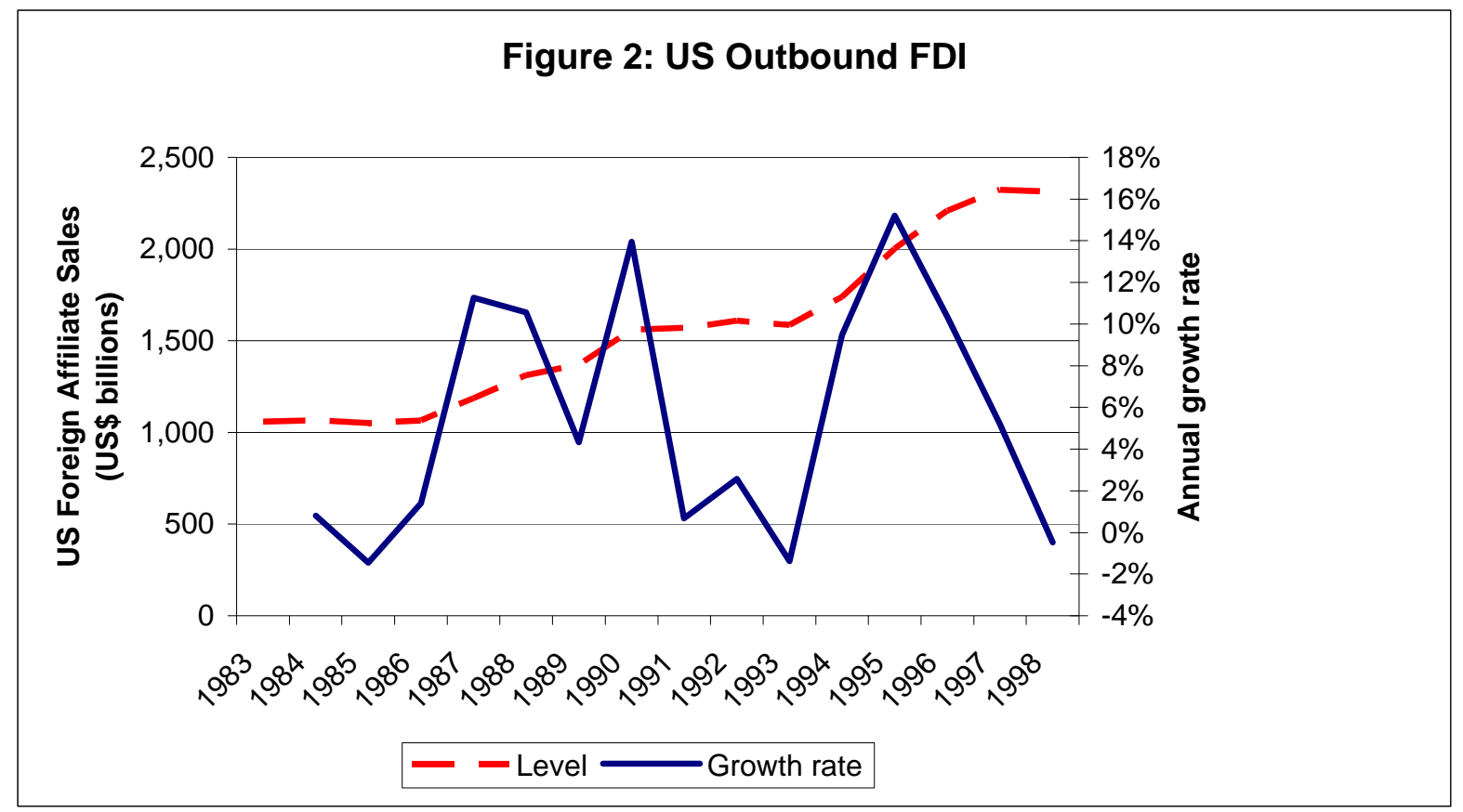

The spectacular growth in FDI suggests that FDI is an important engine of growth. Indeed, FDI may be a key channel of international knowledge and technology spill-over effects emanating from successful economies and this way boost productivity growth of less successful economies. FDI can be an effective way to update technology and skills in producing products for the world market, especially in the development phase. And for the parent company FDI offers access to new retails markets and to cheap labour, buildings and land. Growth rates of individual countries are determined by the world technology frontier (typically, the US) and FDI can help with catching up to the world technology frontier. Cross-country evidence based on detailed firm-level data offered by, for example, Aghion and Griffith (2005) and Griffith, Redding and Simpson (2006) give convincing firm-level evidence of the importance of catching up to the world technology frontier for productivity growth. Caselli and Coleman (2006) offer cross-country

\footnotetext{
${ }^{18}$ The potential growth-enhancing effects of FDI are discussed in more detail in Harding and Rattsø (2008).
} 
evidence on the existence of a world technology frontier. Earlier evidence on diffusion of technology and human capital based on the analysis of barriers to technology adoption and development of Parente and Prescott (1994) has been reviewed in Benhabib and Spiegel (2005).

We learn from the barriers and growth literature that monopoly power, primary and secondary education and good infrastructure are crucial determinants for economies that are trying to benefit from rolling out existing large-scale technologies and catching up to the world possibility frontier. To the extent that FDI embodies know-how and technology, creates new markets and generates demonstration effects, FDI is a crucial factor in catching up with the world productivity frontier, even though FDI may compete with domestic industries for scarce labour, credit and other production factors and crowd out existing industries. FDI (and to some extent foreign trade itself) may even improve the workings of government institutions, open up the economy and motivate other domestic firms to improve their performance and thus catch up to the world technology frontier, although FDI by very large multinationals may also threaten local political autonomy in host countries. FDI seems an important mechanism by which countries improve their position in the world income distribution as described by Acemoglu and Ventura (2002). FDI as a driver of growth seems most relevant for not fully industrialized, middle-income countries with the right type of institutions and reliable governments. ${ }^{19}$ However, once countries approach the world technology frontier they gain much more from competition, higher education and research \& development in order to get a competitive innovation edge and shift the world technology frontier itself. The parable Red Queen of Alice in Wonderland is relevant for advanced economies, since if one does not innovate one falls behind the pack of countries on the world technology frontier.

Alfaro et al. (2004) employ a cross-country analysis to demonstrate empirically that FDI has positive spill-over effects on domestic firms and boosts economic growth only if the host country is blessed with good macroeconomic management, infrastructure and skilled labour, and especially well-developed financial markets. FDI thus seems under the right conditions to be an effective vehicle of knowledge and technology transfer as well as a motor of positive growth externalities. Micro-based evidence also suggests that FDI boost productivity growth. For example, Javorcik (2004) uses firm-level data for Lithuania to establish that there are statistically significant positive productivity spill-over effects from FDI taking place through contacts between foreign affiliates and their local suppliers in upstream sectors, especially for projects with shared domestic and foreign ownership but not for fully owned foreign investments.

\footnotetext{
${ }^{19}$ Blonigen and Wang (2005) stress that the determinants of FDI differ for low-income and high-income countries. They also find that FDI in low-income countries has a greater effect on growth, provided there is enough supply of human capital, and crowds out domestic investment more than in high-income countries.
} 
Javorcik and Spatareanu (2008) arrive at similar conclusions about vertical spill-over effects with Romanian firm-level data. Since FDI appears to be a key engine of growth and cross-country regressions to establish the effects of primacy and urbanization on growth as discussed in section 2 are notoriously difficult to interpret, we have explored the possible effects of primacy of cities and urbanization on growth by investigating in sections 3-7 the indirect effects of primacy of cities and urbanization on FDI. We thus argue that, even if cities have an ambiguous effect on growth, they may boost growth indirectly via FDI.

\section{Concluding Remarks}

According to the United Nations Population Fund, for the first time in history more than half of the human population (3.3 billion people) live in urban areas. Not only are most people concentrated in cities, but the majority of production and of wealth is created in urban centres. Cities rather than countries are increasingly trying to attract multinationals and FDI in order to create wealth for its citizen. One thus wonders whether cities are more important for welfare than the country in which people are living. We have tried to shed some light on this topical question by investigating the empirical evidence for the effects of urbanization, city formation and primacy on FDI and growth performance.

Our empirical evidence suggests that the urban landscape of a country and its neighbours have important implications for how much FDI it is able to attract. Besides the well known effects of distance and market potential, we find that accessible market potential and locations for production in the form of agglomerations appear to be beneficial for FDI flows. The development of local transport infrastructure and new cities of sufficiently large size thus seem to attract more investment by US multinationals. There is a risk that cities grow too large, so that congesting, pollution and over-crowding forces outweigh the positive agglomeration forces. Primacy is usually a sign that cities have grown too large and have become inefficient. Our evidence suggests that such regions will attract relatively less FDI. Our evidence also suggests that high quality institutions as manifested by good rules of law, low corruption and efficient bureaucracy as well as a sound financial system boost FDI. However, after taking into account the presence of natural resources, institutions cease to be important. Cities on the other hand are a much more robust determinant of FDI. Although we could not confirm a robust and significant direct impact of cities on growth performance, there may well be a strong indirect effect of cities on growth as FDI appears to be a strong driver of knowledge and technology transfers and thus of growth.

The regional spatial dimension is also important. Neighbouring attractive locations compete for FDI with locations in the potential host country. So if neighbours suffer from the problem of primacy, bad institutions, restrictions on international trade and not having enough 
cities, it is easier to attract FDI. This suggests that most FDI aims to serve the local market or is motivated by vertical production chains which seek out good locations for production. Goods are then sold on world markets or at home, rather than in the immediate region. Cities therefore do not necessarily function as a regional hub, since surrounding market potential actually decreases FDI in the host country. We have thus shown that urban characteristics of both the host and neighbouring countries matter for FDI and that a better grasp of FDI requires one to unbundle spatial lags. Furthermore, neighbouring urban attributes have different effects than neighbouring economic and institutional characteristics on FDI in the host country.

We tentatively conclude that cities are important for FDI and growth: more medium-sized cities stimulate growth but congestion, pollution and over-crowding associated with mega-cities seem to depress economic performance. Although there may be potential benefits of regional integration for FDI and growth performance as good institutions and high road density in neighbouring countries attract FDI, countries also attract more FDI if their neighbours restrict international trade, are less urbanized and low market potential.

\section{References}

Acemoglu, D. and J. Ventura (2002). The world income distribution, Quarterly Journal of Economics, 117, 659-694.

Acemoglu, D. and S. Johnston (2005) Unbundling institutions, Journal of Political Economy, 113, 5, 949-995.

Ades, A.F. and E.L. Glaeser (1995). Trade and circuses: Explaining urban giants, Quarterly Journal of Economics, 110, 1, 195-227.

Aghion, P. and R. Griffith (2005). Competition and Innovation, Zeuthen Lectures, MIT Press, Cambridge, Mass.

Alfaro, L., A. Chandab, S. Kalemli-Ozcanc and S. Sayekd (2004). FDI and economic growth: The role of financial markets, Journal of International Economics, 64, 89-112.

Amiti, M. and B.S. Javorcik (2008). Trade costs and location of foreign firms in China, Journal of Development Economics, 85, 1-2, 129-149.

Aranello, M. and S. Bond (1991). Some tests of specifications for panel data: Monte Carlo evidence and an application to employment equations, Review of Economic Studies, 58, 277-297.

Baltagi, B.H., P. Egger and M. Pfaffermayer (2007). Estimating models of complex FDI: Are there third-country effects?, Journal of Econometrics, 140, 1, 260-281. 
Barba-Navaretti, G., A.J. Venables, F. Barry, K. Ekholm, A. Falzoni, J. Haaland, K. H. Midelfart and A. Turrini (2004). Multinational Firms in the World Economy, Princeton University Press, Princeton, New Jersey.

Benhabib, J. and M. Spiegel (2005). Human capital and technology diffusion, in P. Aghion and S. Durlauff (eds.), Handbook of Economic Growth, North-Holland, Amsterdam.

Barro, R.J. and J.-W. Lee (2000). International data on educational attainment: updates and implications, Working Paper No. 42, Centre for International Development, Harvard University.

Blonigen, B.A. and M. Wang (2005). Inappropriate pooling of wealthy and poor countries in empirical FDI studies, 221-243 in T. Moran, E. Graham and M. Blomstrom (eds.), Does Foreign Direct Investment Promote Development?, Institute for International Economics, Washington, D.C.

Blonigen, B.A., R.B. Davies, G.R. Waddell and H.T. Naughton (2007). FDI in space: Spatial autoregressive relationships in foreign direct investment, European Economic Review, 51, 1303-1325.

Blundell, R. and S. Bond (1998). Initial conditions and moment restrictions in dynamic panel data models, Journal of Econometrics, 87, 115-143.

Bobonis, G.J. and H.J. Shatz (2007). Agglomeration, adjustment, and state policies in the location of foreign direct investment in the United States, The Review of Economics and Statistics, 89, 1, 30-43.

Bond, S. (2002). Dynamic Panel Data Models: A Guide to Micro Data Methods and Practise, IFS WP CWP09/02.

Bosker, M. (2008). Growth, agglomeration, and convergence: A space-time analysis for European regions, Spatial Economic Analysis, 2, 91-108.

Bosker, M. and H. Garretsen (2008). Economic development and the geography of institutions, Journal of Economic Geography, to appear.

Brülhart, M. and F. Sbergami (2008). Agglomeration and growth: Cross-country evidence, Discussion Paper No. 6941, CEPR, London.

Coughlin, C. and E. Segev (2000). Foreign direct investment in China: a spatial econometric study, The World Economy, 23, 1, 1-23.

Crozet, M. and P. Koenig (2008). The cohesion vs growth tradeoff: Evidence from EU regions. French version in Revue Economique, 59, 2, 331-340.

Davis, J.C. and J.V. Henderson (2003). Evidence on the political economy of the urbanization process, Journal of Urban Economics, 53, 98-125. 
Duranton, G. (2007). From cities to productivity and growth in developing economies, Discussion Paper No. 6634, CEPR, London.

Ekholm, K., R. Forslid and J.R. Markusen (2007). Export-platform foreign direct investment, Journal of the European Economic Association, 5, 4, 776-795.

Garretsen, H. and J. Peeters (2008). FDI and the relevance of spatial linkages: Do third country effects matter for Dutch FDI?, Working Paper 2191, CESifo, Munich.

Griffith, R., S. Redding and H. Simpson (2006). Technological catch-up and the role of multinationals, LSE and University College, London.

Harding, T. and J. Rattsø (2008). Foreign direct investment and economic growth, Report for Norfund, Oslo.

Head, K., J. Ries and D. Swenson (1995). Agglomeration benefits and location choice: Evidence from Japanese manufacturing investments in the United States, Journal of International Economics, 38, 3-4, 223-247.

Head, K. and T. Mayer (2004). Market potential and the location of Japanese investment in the European Union, Review of Economics and Statistics, 86, 4, 959-972.

Helpman, E. (1984). A simple theory of international trade with multinational corporations, Journal of Political Economy, 92, 3, 451-471.

Henderson, V. (2003). The urbanization process and economic growth: The so-what question, Journal of Economic Growth, 8, 47-71.

Henderson, J.V. (2004). Urbanization and growth, in P. Aghion and S. Durlauff (eds.), Handbook of Economic Growth, North-Holland, Amsterdam.

Henderson, J.V., Z. Shalizi and A.J. Venables (2001). Geography and development, Journal of Economic Geography, 1, 81-106.

Heston, A., R. Summers and B. Aten (2006). Penn World Table 6.2, Center for International Comparisons of Production, Income and Prices, University of Pennsylvania.

Javorcik. B.S. (2004). Does foreign direct investment increase the productivity of domestic firms? In search of spillovers through backward linkages, American Economic Review, 94, 3, 605-627.

Javorcik, B.S. and M. Spatareanu (2008). To share or not to share: Does local participation matter for spillovers from foreign direct investment?, Journal of Development Economics, 85, 12, 194-217.

Markusen, J.R. (1984). Multinationals, multi-plant economies, and the gains from trade, Journal of International Economics, 16, 3-4, 205-226.

Markusen, J.R. (2002). Multinational Firms and the Theory of International Trade, MIT Press, Cambridge, Mass. 
Parente, S. and E. Prescott (1994). Barriers to technology adoption and development, Journal of Political Economy, 102, 298-321.

Ploeg, F. van der and S.J. Poelhekke (2008). Globalization and the rise of mega-cities in the developing world, Cambridge Journal of Regions, Economy and Society, 1, 1-25.

Puga, D. and A.J. Venables (1999). Agglomeration economies and economic development; import substitution versus trade liberalization, Economic Journal, 109, 299-311.

Sachs, J.D. and A.M. Warner (1997). Natural resource abundance and economic growth, in G. Meier and J. Raucher (eds.), Leading Issues in Economic Development, Oxford University Press, Oxford.

Scott, A.J., J. Agnew, E.W. Soja and M. Storper (2001). Global city-regions: An overview, in A.J. Scott (ed.), Global City Regions, Oxford University Press, Oxford.

United Nations, (2007). World Urbanization Prospects 2007, New York.

Venables, A.J. (2005). Spatial disparities in developing economies: Cities, regions and international trade, Journal of Economic Geography, 5, 3-21.

Vincenty, T. (1975). Direct and inverse solutions of geodesics on the ellipsoid with application of nested equations, Survey Review, 23, 176, 88-93.

Wacziarg, R. and K.H. Welsch (2003). Trade liberalization and growth: new evidence, Working Paper No. 10152, NBER, Cambridge, MA.

Wheeler, D. and A. Mody (1992). International investment location decisions: The case of US firms, Journal of International Economics, 33, 57-76.

Williamson, J.G. (1965). Regional inequality and the process of national development, Economic Development and Cultural Change, 13, 4, 3-45.

World Bank (2008). World Development Report 2009: Reshaping Economic Geography, Washington, D.C. 


\section{Appendix 1: Description of the Data for the Growth Regressions}

\section{Descriptive Statistics*}

\begin{tabular}{|c|c|c|c|c|}
\hline & Mean & \begin{tabular}{|l|} 
Std. Dev. \\
\end{tabular} & Min & Max \\
\hline FDI (US\$ millions) & 22,287 & 48,966 & 1 & 350,173 \\
\hline Distance to US & 5,160 & 2,488 & 455 & 10,163 \\
\hline Skill level & 5.81 & 2.67 & 0.37 & 11.82 \\
\hline Openness & 0.66 & 0.47 & 0.00 & 1.00 \\
\hline Financial Development & $51.2 \%$ & $38.4 \%$ & $0.0 \%$ & $180.5 \%$ \\
\hline Institutions & 9.85 & 4.05 & 1.00 & 16.17 \\
\hline GDP per capita & 9,892 & 8,056 & 602 & 31,948 \\
\hline Road Density (km/land area) & 0.67 & 0.96 & 0.01 & 4.70 \\
\hline Landlocked & 0.13 & 0.33 & 0.00 & 1.00 \\
\hline Urbanization level & $56.2 \%$ & $24.0 \%$ & $8.5 \%$ & $100.0 \%$ \\
\hline Primacy & $38.9 \%$ & $27.4 \%$ & $2.6 \%$ & $100.0 \%$ \\
\hline Number of Cities, absolute & 6.52 & 18.78 & 1 & 138 \\
\hline $\begin{array}{l}\text { Number of Cities, internal distance } \\
\text { weighted in equivalents of } 750,000 \\
\text { inhabitants** }\end{array}$ & 0.006 & 0.007 & 0.000 & 0.046 \\
\hline GDP (US\$ billions) & 308 & 544 & 3 & 4,315 \\
\hline Population (thousands) & 56,727 & 171,455 & 241 & $1,241,891$ \\
\hline \multicolumn{5}{|l|}{ Spatially weighted variables*** } \\
\hline Financial Development & 1.27 & 0.77 & 0.36 & 4.67 \\
\hline Institutions & 24.31 & 13.50 & 6.43 & 75.00 \\
\hline GDP per capita & 26,834 & 20,135 & 7,076 & 117,670 \\
\hline Road Density & 1.82 & 1.67 & 0.31 & 8.79 \\
\hline Urbanization level & 1.49 & 0.72 & 0.46 & 3.83 \\
\hline Primacy & 1.27 & 0.45 & 0.50 & 2.64 \\
\hline $\begin{array}{l}\text { Number of Cities, external distance } \\
\text { weighted in equivalents of } 750,000 \\
\text { inhabitants** }\end{array}$ & 0.002 & 0.001 & 0.000 & 0.007 \\
\hline Openness & 1.73 & 1.02 & 0.32 & 5.17 \\
\hline GDP (US\$ billions) & 723 & 464 & 224 & 2,888 \\
\hline
\end{tabular}

* See Appendix 2 for definitions. Table refers to the sample of regression 3, Table 5.

** Internal refers to the number of cities weighted by their distance to the largest host city within the same country. External refers to the number of cities weighted by their distance to the largest host city where all world cities are included.

*** Weights are the distance between country centroids. 
Appendix 2: Description of the Data for FDI and Its Determinants

\begin{tabular}{|c|c|c|}
\hline Variable $^{20}$ & Mnenomic & Definition \\
\hline FDI & Infdi & FDI, from Blonigen et al. 2007: US affiliate sales abroad \\
\hline distance to US & In_dist & $\begin{array}{l}\text { Vincenty distance in km between country centroids, CID } \\
\text { data }\end{array}$ \\
\hline $\begin{array}{l}\text { skill level, average years of } \\
\text { total schooling }\end{array}$ & Inhumanav & Barro and Lee (2000) years of schooling, 5 year average \\
\hline openness & openness & Sachs \& Warner openness, updates by Wacziarg \& Welch \\
\hline financial development & Infindev & Private credit as share of GDP \\
\hline $\begin{array}{l}\text { institutions (rule of law, } \\
\text { corruption, bureaucracy) }\end{array}$ & lninst & $\begin{array}{l}\text { In Institutions (Corruption, rule of law, bureaucracy, higher = } \\
\text { less risk), from International Country Risk Guide }\end{array}$ \\
\hline Investment share of GDP & & $\begin{array}{l}\text { Gross fixed capital formation as \% of GDP, PWT } 6.2 \text { from } \\
\text { Heston et al (2006) }\end{array}$ \\
\hline Trade costs & Intc & Inverse of exports plus imports as a share of GDP. PWT 6.2 \\
\hline Investment costs & lninvcost & $\begin{array}{l}\text { Inverse of composite index composite index comprising } \\
\text { operations risk index, political risk index and remittance and } \\
\text { repatriation factor index, developed by Business } \\
\text { Environment Risk Intelligence S.A. (Blonigen et al., 2007) }\end{array}$ \\
\hline road density & Inroadens & $\begin{array}{l}\text { Length of road network / surface area. International Road } \\
\text { Federation. }\end{array}$ \\
\hline GDP & lngdp & GDP in constant \$ billions, PPP, PWT6.2 \\
\hline population & In_poptot & PWT 6.2 \\
\hline $\begin{array}{l}\text { 5-year average yearly growth } \\
\text { in GDP per capita }\end{array}$ & d_gdppc & $\begin{array}{l}\text { GDP per capita yearly growth rate averaged over } 5 \text { years } \\
\text { intervals between } 1960-2000 \text {. PWT 6.2. }\end{array}$ \\
\hline $\begin{array}{l}\text { Average yearly population } \\
\text { growth rate }\end{array}$ & & $\begin{array}{l}\text { Ln difference in total population, PWT } 6.2 \text { from Heston et al } \\
(2006)\end{array}$ \\
\hline$\%$ urban & urbpav & $\begin{array}{l}\text { Urban population as share of total population. } \\
\text { World Urbanization Prospects } 2007\end{array}$ \\
\hline primacy & primacy & Population of largest city as a share of total urban population \\
\hline $\log$ GDP/capita & lngdppc & PWT6.2 \\
\hline number of cities & Incitycountall & Those cities with at least 750000 people in 2007, WUP2007 \\
\hline $\begin{array}{l}\text { distance weighted number of } \\
\text { standard size cities }\end{array}$ & Incitynumber_mp & $\begin{array}{l}\text { Those cities with at least } 750000 \text { people in } 2007 \text { within the } \\
\text { same country, WUP2007, weighted by their distance from } \\
\text { the largest city, normalized to shortest distance in sample } \\
\text { (Brazzaville - Kinshasa, } 10.4 \mathrm{~km} \text { ) }\end{array}$ \\
\hline Point-source resources & Innatpoint & $\begin{array}{l}\text { In share of point-source natural resource exports in GDP. } \\
\text { World Bank (2006) }\end{array}$ \\
\hline
\end{tabular}

\footnotetext{
${ }^{20}$ The following variables are observed only every 5 years, where we impute missing years with the value of the most recent year such that FDI is regressed on beginning of period (5 yearly) values of explanatory variables: lnhumanav, lninst, lnroadens, urbpav, primacy, lncitycountall, lncitynumber_mp and their spatial lags.
} 


\begin{tabular}{|l|l|l|}
\hline Spatial lags: & & \\
\hline GDP & Ingdp_smp & $\begin{array}{l}\text { idem, country centroid distance weighted sum of variable, } \\
\text { normalized by shortest distance (Netherlands Belgium, 115.4 km) }\end{array}$ \\
\hline population & Inpoptot_smp & $\begin{array}{l}\text { idem, country centroid distance weighted sum of variable, } \\
\text { normalized by shortest distance (Netherlands Belgium, 115.4 km) }\end{array}$ \\
\hline $\begin{array}{l}\text { primacy (easily accessible } \\
\text { mp) }\end{array}$ & primacy_smp & $\begin{array}{l}\text { idem, country centroid distance weighted sum of variable, } \\
\text { normalized by shortest distance(Netherlands Belgium, 115.4 km) }\end{array}$ \\
\hline GDP/capita (wages) & lngdppc_smp & $\begin{array}{l}\text { idem, country centroid distance weighted sum of variable, } \\
\text { normalized by shortest distance (Netherlands Belgium, 115.4 km) }\end{array}$ \\
\hline $\begin{array}{l}\text { distance weighted number of } \\
\text { standard size cities }\end{array}$ & Incitynumber_smp & $\begin{array}{l}\text { Those cities with at least 750000 people in 2007, all countries, } \\
\text { WUP2007, weighted by their distance from the largest city in the } \\
\text { country, normalized by shortest distance in sample (Brazzaville - } \\
\text { Kinshasa, 10.4 km) }\end{array}$ \\
\hline openness & $\begin{array}{l}\text { idem, country centroid distance weighted sum of variable, } \\
\text { normalized by shortest distance (Netherlands Belgium, 115.4 km) }\end{array}$ \\
\hline financial development & lnfindev_smp & $\begin{array}{l}\text { idem, country centroid distance weighted sum of variable, } \\
\text { normalized by shortest distance (Netherlands Belgium, 115.4 km) }\end{array}$ \\
\hline $\begin{array}{l}\text { institutions (rule of law, } \\
\text { corruption, bureaucracy) }\end{array}$ & Ininst_smp & $\begin{array}{l}\text { idem, country centroid distance weighted sum of variable, } \\
\text { normalized by shortest distance (Netherlands Belgium, 115.4 km) }\end{array}$ \\
\hline road density & $\begin{array}{l}\text { idem, country centroid distance weighted sum of variable, } \\
\text { normalized by shortest distance (Netherlands Belgium, 115.4 km) }\end{array}$ \\
\hline Point-source resources & lnnatpoint_smp & $\begin{array}{l}\text { In share of point-source natural resource exports in GDP, } \\
\text { surrounding. World Bank (2006) }\end{array}$ \\
\hline
\end{tabular}

Appendix 3: Country sample used in Table 4*

\begin{tabular}{|l|l|l|l|l|l|l|l|l|l|}
\hline Algeria & 0 & Dominican Republic & 0 & Iran, Islamic Rep. & 0 & Nicaragua & 0 & Switzerland & 1 \\
\hline Argentina & 1 & Ecuador & 0 & Ireland & 1 & Niger & 0 & Syrian Arab Republic & 0 \\
\hline Australia & 1 & Egypt, Arab Rep. & 1 & Israel & 1 & Norway & 1 & Thailand & 1 \\
\hline Austria & 1 & El Salvador & 0 & Italy & 1 & Pakistan & 0 & Togo & 0 \\
\hline Bangladesh & 0 & Finland & 1 & Jamaica & 0 & Panama & 0 & Trinidad and Tobago & 0 \\
\hline Belgium & 1 & France & 1 & Japan & 1 & Papua New Guinea & 0 & Turkey & 1 \\
\hline Bolivia & 0 & Germany & 1 & Jordan & 0 & Paraguay & 0 & Uganda & 0 \\
\hline Botswana & 0 & Ghana & 0 & Kenya & 0 & Peru & 0 & United Kingdom & 1 \\
\hline Brazil & 1 & Greece & 1 & Korea, Rep. & 1 & Philippines & 1 & Uruguay & 0 \\
\hline Canada & 1 & Guatemala & 0 & Malawi & 0 & Portugal & 1 & Venezuela, RB & 1 \\
\hline Chile & 1 & Haiti & 0 & Malaysia & 1 & Senegal & 0 & Zambia & 0 \\
\hline China & 0 & Honduras & 0 & Mali & 0 & Singapore & 1 & Zimbabwe & 0 \\
\hline Colombia & 1 & Hong Kong, China & 0 & Mexico & 1 & South Africa & 1 & & \\
\hline Costa Rica & 0 & Iceland & 0 & Mozambique & 0 & Spain & 1 & & \\
\hline Cyprus & 0 & India & 0 & Netherlands & 1 & Sri Lanka & 0 & & \\
\hline Denmark & 1 & Indonesia & 1 & New Zealand & 0 & Sweden & 1 & & \\
\hline
\end{tabular}

* Numbers refer to whether a country is included in regression 1 of Table 4 (1) or not (0). 


\section{CESifo Working Paper Series}

for full list see www.cesifo-group.org/wp

(address: Poschingerstr. 5, 81679 Munich, Germany, office@cesifo.de)

2413 Thorsten Upmann, Labour Unions - To Unite or to Separate?, October 2008

2414 Sascha O. Becker and Ludger Woessmann, Luther and the Girls: Religious Denomination and the Female Education Gap in $19^{\text {th }}$ Century Prussia, October 2008

2415 Florian Englmaier and Stephen Leider, Contractual and Organizational Structure with Reciprocal Agents, October 2008

2416 Vittorio Daniele and Ugo Marani, Organized Crime and Foreign Direct Investment: The Italian Case, October 2008

2417 Valentina Bosetti, Carlo Carraro, Alessandra Sgobbi and Massimo Tavoni, Modelling Economic Impacts of Alternative International Climate Policy Architectures. A Quantitative and Comparative Assessment of Architectures for Agreement, October 2008

2418 Paul De Grauwe, Animal Spirits and Monetary Policy, October 2008

2419 Guglielmo Maria Caporale, Christophe Rault, Robert Sova and Anamaria Sova, On the Bilateral Trade Effects of Free Trade Agreements between the EU-15 and the CEEC-4 Countries, October 2008

2420 Yin-Wong Cheung and Daniel Friedman, Speculative Attacks: A Laboratory Study in Continuous Time, October 2008

2421 Kamila Fialová and Ondřej Schneider, Labour Market Institutions and their Effect on Labour Market Performance in the New EU Member Countries, October 2008

2422 Alexander Ludwig and Michael Reiter, Sharing Demographic Risk - Who is Afraid of the Baby Bust?, October 2008

2423 Doina Maria Radulescu and Michael Stimmelmayr, The Welfare Loss from Differential Taxation of Sectors in Germany, October 2008

2424 Nikolaus Wolf, Was Germany ever United? Evidence from Intra- and International Trade 1885 - 1933, October 2008

2425 Bruno S. Frey, David A. Savage and Benno Torgler, Noblesse Oblige? Determinants of Survival in a Life and Death Situation, October 2008

2426 Giovanni Facchini, Peri Silva and Gerald Willmann, The Customs Union Issue: Why do we Observe so few of them?, October 2008 
2427 Wido Geis, Silke Uebelmesser and Martin Werding, Why go to France or Germany, if you could as well go to the UK or the US? Selective Features of Immigration to four major OECD Countries, October 2008

2428 Geeta Kingdon and Francis Teal, Teacher Unions, Teacher Pay and Student Performance in India: A Pupil Fixed Effects Approach, October 2008

2429 Andreas Haufler and Marco Runkel, Firms' Financial Choices and Thin Capitalization Rules under Corporate Tax Competition, October 2008

2430 Matz Dahlberg, Heléne Lundqvist and Eva Mörk, Intergovernmental Grants and Bureaucratic Power, October 2008

2431 Alfons J. Weichenrieder and Tina Klautke, Taxes and the Efficiency Costs of Capital Distortions, October 2008

2432 Andreas Knabe and Ronnie Schöb, Minimum Wage Incidence: The Case for Germany, October 2008

2433 Kurt R. Brekke and Odd Rune Straume, Pharmaceutical Patents: Incentives for R\&D or Marketing?, October 2008

2434 Scott Alan Carson, Geography, Insolation, and Institutional Change in $19^{\text {th }}$ Century African-American and White Stature in Southern States, October 2008

2435 Emilia Del Bono and Daniela Vuri, Job Mobility and the Gender Wage Gap in Italy, October 2008

2436 Marco Angrisani, Antonio Guarino, Steffen Huck and Nathan Larson, No-Trade in the Laboratory, October 2008

2437 Josse Delfgaauw and Robert Dur, Managerial Talent, Motivation, and Self-Selection into Public Management, October 2008

2438 Christian Bauer and Wolfgang Buchholz, How Changing Prudence and Risk Aversion Affect Optimal Saving, October 2008

2439 Erich Battistin, Clara Graziano and Bruno Parigi, Connections and Performance in Bankers' Turnover: Better Wed over the Mixen than over the Moor, October 2008

2440 Erkki Koskela and Panu Poutvaara, Flexible Outsourcing and the Impacts of Labour Taxation in European Welfare States, October 2008

2441 Marcelo Resende, Concentration and Market Size: Lower Bound Estimates for the Brazilian Industry, October 2008

2442 Giandomenico Piluso and Roberto Ricciuti, Fiscal Policy and the Banking System in Italy. Have Taxes, Public Spending and Banks been Procyclical in the Long-Run? October 2008 
2443 Bruno S. Frey and Katja Rost, Do Rankings Reflect Research Quality?, October 2008

2444 Guglielmo Maria Caporale, Antoaneta Serguieva and Hao Wu, Financial Contagion: Evolutionary Optimisation of a Multinational Agent-Based Model, October 2008

2445 Valentina Bosetti, Carlo Carraro and Massimo Tavoni, Delayed Participation of Developing Countries to Climate Agreements: Should Action in the EU and US be Postponed?, October 2008

2446 Alexander Kovalenkov and Xavier Vives, Competitive Rational Expectations Equilibria without Apology, November 2008

2447 Thiess Buettner and Fédéric Holm-Hadulla, Cities in Fiscal Equalization, November 2008

2448 Harry H. Kelejian and Ingmar R. Prucha, Specification and Estimation of Spatial Autoregressive Models with Autoregressive and Heteroskedastic Disturbances, November 2008

2449 Jan Bouckaert, Hans Degryse and Thomas Provoost, Enhancing Market Power by Reducing Switching Costs, November 2008

2450 Frank Heinemann, Escaping from a Combination of Liquidity Trap and Credit Crunch, November 2008

2451 Dan Anderberg, Optimal Policy and the Risk Properties of Human Capital Reconsidered, November 2008

2452 Christian Keuschnigg and Evelyn Ribi, Outsourcing, Unemployment and Welfare Policy, November 2008

2453 Bernd Theilen, Market Competition and Lower Tier Incentives, November 2008

2454 Ondřej Schneider, Voting in the European Union - Central Europe's Lost Voice, November 2008

2455 Oliver Lorz and Gerald Willmann, Enlargement versus Deepening: The Trade-off Facing Economic Unions, November 2008

2456 Alfons J. Weichenrieder and Helen Windischbauer, Thin-Capitalization Rules and Company Responses, Experience from German Legislation, November 2008

2457 Andreas Knabe and Steffen Rätzel, Scarring or Scaring? The Psychological Impact of Past Unemployment and Future Unemployment Risk, November 2008

2458 John Whalley and Sean Walsh, Bringing the Copenhagen Global Climate Change Negotiations to Conclusion, November 2008

2459 Daniel Mejía, The War on Illegal Drugs in Producer and Consumer Countries: A Simple Analytical Framework, November 2008 
2460 Carola Frydman, Learning from the Past: Trends in Executive Compensation over the Twentieth Century, November 2008

2461 Wolfgang Ochel, The Political Economy of Two-tier Reforms of Employment Protection in Europe, November 2008

2462 Peter Egger and Doina Maria Radulescu, The Influence of Labor Taxes on the Migration of Skilled Workers, November 2008

2463 Oliver Falck, Stephan Heblich and Stefan Kipar, The Extension of Clusters: Differencein-Differences Evidence from the Bavarian State-Wide Cluster Policy, November 2008

2464 Lei Yang and Keith E. Maskus, Intellectual Property Rights, Technology Transfer and Exports in Developing Countries, November 2008

2465 Claudia M. Buch, The Great Risk Shift? Income Volatility in an International Perspective, November 2008

2466 Walter H. Fisher and Ben J. Heijdra, Growth and the Ageing Joneses, November 2008

2467 Louis Eeckhoudt, Harris Schlesinger and Ilia Tsetlin, Apportioning of Risks via Stochastic Dominance, November 2008

2468 Elin Halvorsen and Thor O. Thoresen, Parents' Desire to Make Equal Inter Vivos Transfers, November 2008

2469 Anna Montén and Marcel Thum, Ageing Municipalities, Gerontocracy and Fiscal Competition, November 2008

2470 Volker Meier and Matthias Wrede, Reducing the Excess Burden of Subsidizing the Stork: Joint Taxation, Individual Taxation, and Family Splitting, November 2008

2471 Gunther Schnabl and Christina Ziegler, Exchange Rate Regime and Wage Determination in Central and Eastern Europe, November 2008

2472 Kjell Erik Lommerud and Odd Rune Straume, Employment Protection versus Flexicurity: On Technology Adoption in Unionised Firms, November 2008

2473 Lukas Menkhoff, High-Frequency Analysis of Foreign Exchange Interventions: What do we learn?, November 2008

2474 Steven Poelhekke and Frederick van der Ploeg, Growth, Foreign Direct Investment and Urban Concentrations: Unbundling Spatial Lags, November 2008 